\title{
Long-Term Variability of Extreme Significant Wave Height in the South China Sea
}

\author{
Adekunle Osinowo, ${ }^{1}$ Xiaopei Lin, ${ }^{1}$ Dongliang Zhao, ${ }^{1}$ and Zhifeng Wang ${ }^{2}$ \\ ${ }^{1}$ College of Physical and Environmental Oceanography, Ocean University of China, Qingdao 266100, China \\ ${ }^{2}$ College of Engineering, Ocean University of China, Qingdao 266100, China
}

Correspondence should be addressed to Adekunle Osinowo; voxfox99@yahoo.com

Received 31 March 2016; Revised 25 July 2016; Accepted 1 September 2016

Academic Editor: Enrico Ferrero

Copyright (c) 2016 Adekunle Osinowo et al. This is an open access article distributed under the Creative Commons Attribution License, which permits unrestricted use, distribution, and reproduction in any medium, provided the original work is properly cited.

\begin{abstract}
This paper describes long-term spatiotemporal trends in extreme significant wave height (SWH) in the South China Sea (SCS) based on 30-year wave hindcast. High-resolution reanalysis wind field data sets are employed to drive a spectral wave model WAVEWATCH III ${ }^{\mathrm{TM}}$ (WW3). The wave hindcast information is validated using altimeter wave information (Topex/Poseidon). The model performance is satisfactory. Subsequently, the trends in yearly/seasonal/monthly mean extreme SWH are analyzed. Results showed that trends greater than $0.05 \mathrm{~m} \mathrm{yr}^{-1}$ are distributed over a large part of the central SCS. During winter, strong positive trends $\left(0.07-0.08 \mathrm{~m} \mathrm{yr}^{-1}\right)$ are found in the extreme northeast SCS. Significant trends greater than $0.01 \mathrm{~m} \mathrm{yr}^{-1}$ are distributed over most parts of the central SCS in spring. In summer, significant increasing trends $\left(0.01-0.05 \mathrm{~m} \mathrm{yr}^{-1}\right)$ are distributed over most regions below latitude $16^{\circ} \mathrm{N}$. During autumn, strong positive trends between 0.02 and $0.08 \mathrm{~m} \mathrm{yr}^{-1}$ are found in small regions above latitude $12^{\circ} \mathrm{N}$. Increasing positive trends are found to be generally significant in the central SCS in December, February, March, and July. Furthermore, temporal trend analysis showed that the extreme SWH exhibits a significant increasing trend of $0.011 \mathrm{~m} \mathrm{yr}^{-1}$. The extreme SWH exhibits the strongest increasing trend of $0.03 \mathrm{~m} \mathrm{yr}^{-1}$ in winter and showed a decreasing trend of $-0.0098 \mathrm{~m} \mathrm{yr}^{-1}$ in autumn.
\end{abstract}

\section{Introduction}

Wave climatology has been traditionally based on buoy measurements and ship observations. The former provide accurate but spatially scarce information on wave parameters, whereas the latter provide limited spatiotemporal coverage during extreme conditions [1]. However, these are still quite inadequate to estimate long-term trends in ocean wave parameters.

Wave modeling (hindcasting) is one of the major sources of wave data that gives high-resolution (spatial and temporal) long-term wave information in areas sparsely covered with buoy measurements. Wave modeling excellence strongly depends on accurate wind fields covering the study area and the simulation period.

It is necessary to understand the spatial and temporal variability of the wave climate for a good assessment of the impact of changes in waves on coastal and offshore environments. Long-term changes in wave characteristics can modify the profile of the coast and the shape of sandy beaches through changes in nearshore circulation and sediment transport characteristics $[2,3]$.

By using a time-dependent extreme value model, [4] carried out a work on the long-term variability of extreme SWH along the Northeast Pacific with 23-year SWH data got from 26 buoys. The authors concluded in their work that significant positive long-term trends of extreme wave heights exist between latitudes 30 and $45^{\circ} \mathrm{N}$ close to the western coast of the US.

A number of studies on wave climate variability over the eastern north pacific using mean or high percentiles of SWH but not the largest extreme wave heights were also carried out by [5-10].

Statistical models to estimate long-term trends in frequency and intensity of severe storm waves, based on timedependent versions of the Peak over Threshold model, are 
applied by [11] to investigate storminess trends in the Australian southern ocean. Results suggested that positive trends in high percentile wave heights observed in the ERA-40 waves reanalysis west and south of Tasmania are a sign of increasing frequency of storm wave events in the record, with no obvious change in intensity of events.

For coastal and ocean engineering, the knowledge of both mean and extreme wave climate is highly relevant in the construction of coastal and offshore structure, ship routing, and the function of oceanic structures. It is also useful in the area of coastal management and maritime works in an attempt to provide references for the wave energy resources development, navigation, marine engineering, and disaster prevention and reduction.

Research on global wave states confirms that, in the last decades, average and severe conditions (90th- and 99thpercentile values) may have risen (e.g., [12-17]). If such conditions have enlarged, then it is likely that extreme wave height values may also have changed. A good knowledge of the potential level of such changes is vital for the applications stated earlier. For example, the construction of coastal and offshore facilities may be insufficient if extreme wave height values are rising.

Global satellite data are now accessible over several decades and have been used for climatological purpose (e.g., [18-20]), extreme value return period wave height (e.g., [21$25]$ ), and trends in average and percentile values [14, 16, 17].

Many researches use studies on wave model reanalysis to examine trends in significant wave height. Reference [26] found gradually rising trends in the North Atlantic for increasing extreme significant wave height value for the period 1955-1994 (0.025-0.075 $\mathrm{m} \mathrm{decade}^{-1}$ for mean, $0.1-0.2 \mathrm{~m} \mathrm{decade}^{-1}$ for the 90 th percentile, and $0.3-$ 0.4 m decade $^{-1}$ for the 99 th percentile). By using 23 years of altimeter data (1991-2008), [17] found trends getting increasingly positive at 99th-percentile values. An average over the globe shows that the trends are relatively neutral (0.04 m decade $^{-1}$ : mean; $0.04 \mathrm{~m} \mathrm{decade}^{-1}$ : 90 th percentile; $0.07 \mathrm{~m} \mathrm{decade}^{-1}$ : 99th percentile). Reference [27] compiled an altimeter data set covering nearly 23 years (1991-2008) from seven altimeter missions. The data set was used to examine trends in mean and 90th- and 99th-percentile values of wave height by [17] and to find out 100-year extreme value return period estimates [25].

Reference [17] used the data set of calibrated and validated satellite altimeter measurements to examine whether there is systematic variation in the global ocean wave climate during 1985-2008. The linear trends in the annual mean and 90th- and 99th-percentile values of wave height are analyzed. Young et al. observed that extreme wave height is rising at a faster rate than the mean conditions. The global mean wave height trend is nearly neutral. The 99th-percentile wave height trends are progressively more positive, with higher latitudes (greater than $\pm 35^{\circ}$ ) of both hemispheres. The equatorial and tropical regions of all oceanic basins show a neutral trend for wave height in both the 90th- and 99th-percentile cases. The wave height trend becomes more positive moving from the mean to the 99th percentile (i.e., moving to more extreme conditions). For the 99th-percentile wave height, the stronger positive trends at high latitudes are statistically significant, whereas the weaker trends in the equatorial regions are not.

The wave climate of US West Coast has been investigated by [28] with data got from ten NDBC buoys at latitudes from Washington to south central California. Allan and Komar reported a trend of rising wave heights during at least the past 25 years which might be linked with global warming and El Niño Southern Oscillation (ENSO) range between El Niños and La Niñas which affects the annual wave conditions and monthly average water levels that increase tidal elevations.

Reference [29] analyzed the daily measurements of wave heights since the 1970s taken by three National Data Buoy Center (NDBC) buoys along the central US East Coast and a buoy in the Gulf of Mexico. Analyses were undertaken during summer in the months of July, August, and September to record waves produced by hurricanes and for months of November through March during winter to record waves generated by extratropical storms (nor'easters). From the analyses, Komar and Allan concluded a continual increase in wave height for the three Atlantic buoys in summer months during which hurricanes are most significant to the generation of waves, and waves generated by extratropical storms during winter for the aforementioned Atlantic buoys do not statistically have any significant change.

The analyses presented by [30] focused on wave data collected since mid-1970s in deep water off the coast of the US Pacific Northwest (Oregon and Washington), with buoy 46005 of NDBC. They documented an increase $\left(0.015 \mathrm{~m} \mathrm{yr}^{-1}\right)$ in the annual average wave height, whereas averages during winter, that is, October through March, increased at a higher rate of $0.023 \mathrm{~m} / \mathrm{yr}$. They further reported that the averages of the 5 largest wave heights measured each year increased at a rate of $0.071 \mathrm{~m} / \mathrm{yr}$, and, for the annual maximum wave heights, there had been an increasing rate of $0.095 \mathrm{~m} / \mathrm{yr}$. All of the trends were statistically significant at the $95 \%$ confidence level.

The long-term variability and wave characteristic trends in the southern region of the SCS were investigated by [31] using 31-year hindcast data derived from the state-of-the-art WAVEWATCH III spectral wave model forced with Climate Forecast System Reanalysis winds. The detailed hindcast demonstrates strong interannual variability of wave heights, especially during the winter months in the SCS. Significant positive trends were found during May, July, and September. Significant negative trend was found in December covering the Sunda shelf region. However, the trend appears to be largely influenced by large El Niño signals.

In this study, we extend the work by [31] by investigating the long-term spatiotemporal trends in extreme SWH in the whole of SCS over a 30-year period. In comparison with a previous study by [32], this study will analyze the 30year hindcast data to examine whether statistically significant trends in 100-year return period extreme wave height have occurred over this period. Furthermore, linear trends in wave heights for the SCS will be compared with other previous studies by $[4,17,28-30]$. 
The rest of this paper is organised as follows. The data set and methodology used in this study and the model setup and validation are all given in Section 2 . The results, followed by a detailed discussion, are stated in Section 3, and Section 4 concludes the paper.

\section{Models, Data Sets, and Methodology}

2.1. The Wave Model and Input Data. The model used for wave simulation is version 3.14 of the third-generation spectral wave model WAVEWATCH III (denoted by WW3), [30]. WW3 was developed at the Ocean Modeling Branch of the Environmental Modeling Center of the National Centers for Environmental Prediction (NCEP) for the regional sea wave prediction. It was built on the base of WAVEWATCH I and WAVEWATCH II as developed at the Delft University of Technology and NASA Goddard Space Flight Center, respectively [33]. By using the NGDC (National Geophysical Data Center) ETOPO 1 data, with a resolution of $0.5^{\circ} \times 0.5^{\circ}$, the SCS water depth field was processed by the Gridgen 3.0 packet. Source terms for energy spectra in the model are set to default. The model integrates the spectrum to a cutoff frequency, and above this frequency a parametric tail is applied. The boundary condition is cyclical. The other option settings are 36 directions and 24 discrete wavenumbers $(0.0412 \sim 0.4060 \mathrm{~Hz}, 2.4 \sim 24.7 \mathrm{~s})$. The model spatial grid covers the whole of the SCS and part of East China Sea from longitudes $95^{\circ} \mathrm{E}$ to $135^{\circ} \mathrm{E}$ and latitudes $5^{\circ} \mathrm{S}$ to $30^{\circ} \mathrm{N}$ with a $0.25^{\circ}$ resolution (Figure 1). The model in an operational/forecasting mode was forced with 6-hour reanalysis wind fields extracted over longitudes $95^{\circ} \mathrm{E}$ to $135^{\circ} \mathrm{E}$ and latitudes $5^{\circ} \mathrm{S}$ to $30^{\circ} \mathrm{N}$ from the weather research and forecasting (WRF) model from 1976 to 2005 on a $0.2^{\circ}$ (longitude) by $0.2^{\circ}$ (latitude) Gaussian grid. Wind fields were interpolated on a regular $0.25^{\circ}$ grid to force the model. The model output is a two-dimensional (2D) wave energy spectrum obtained at each grid point with time period spanning from 1 January 1976 to 31 December 2005 and with 6-hour output data. The model provides output of wave parameters including wave spectra, SWH $(4 \sqrt{ } E)$, mean wavelength $\left(2 \Pi k^{-1}\right)$, mean wave period $\left(2 \Pi k^{-1} 2 \pi\right)$, mean wave direction, peak frequency, and peak direction. The simulation provided a 6-hour time series of SWH and other wave parameters over a box extending from $3^{\circ} \mathrm{N}$ to $23^{\circ} \mathrm{N}$ and $105^{\circ} \mathrm{E}$ to $121^{\circ} \mathrm{E}$ which contains the main part of SCS and surrounding waters. The available satellite data used in this study served as independent observations against which the modeled values were evaluated so no assimilation procedure was employed.

2.2. Satellite Data and Model Verification. The observation data used in this study were obtained from Topex/Poseidon (NASA/CNES) which is an official remote sensing data center that has data containing near-real-time gridded observations for SWH. The Topex/Poseidon satellite, jointly launched by NASA and the French Space Agency, Centre National d'Etudes Spatiales (CNES) in August 1992, carried a stateof-the-art radar altimetry system [34]. In addition to precise measurements of the distance between the satellite and the

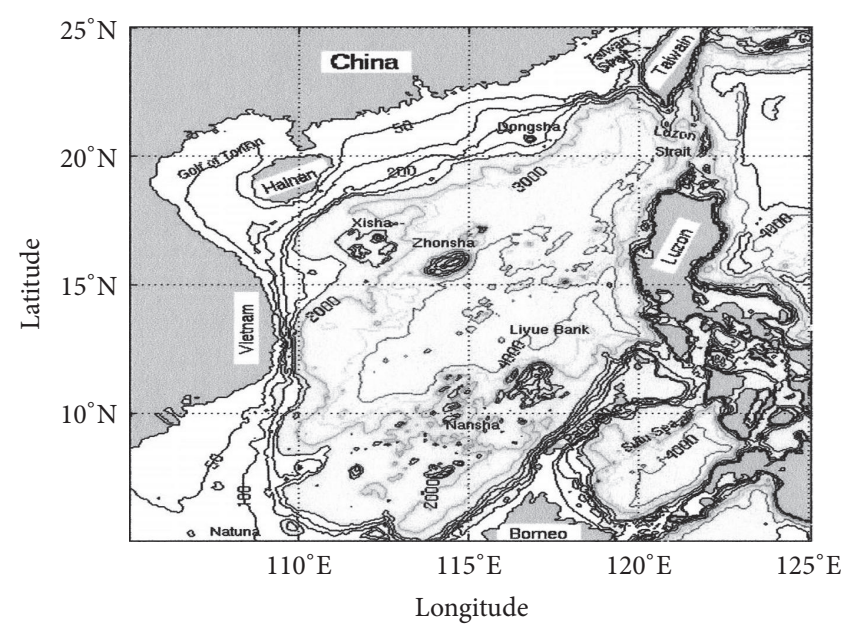

FIGURE 1: Geography of the SCS.

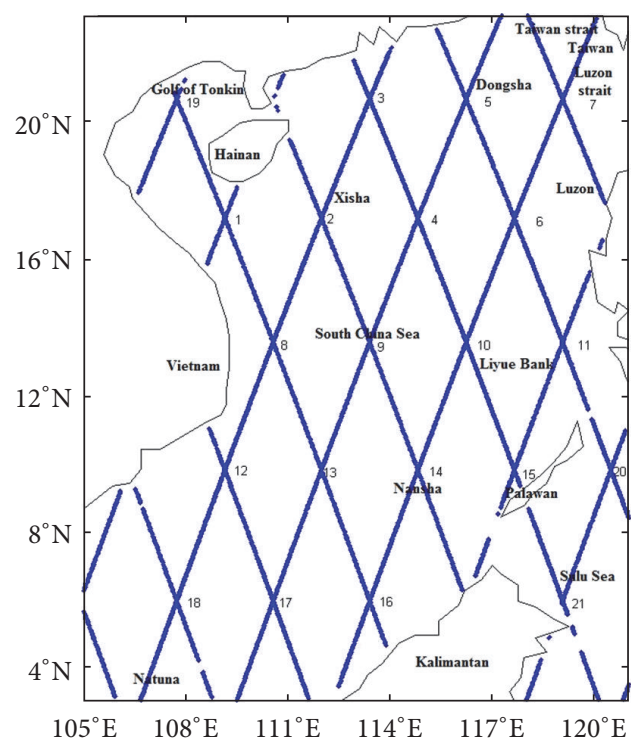

FIgure 2: Topex/Poseidon crossover points in the SCS.

surface, SWH was derived from the shape of the leading edge of the returning radar pulse. The accuracy of SWH measurement by Topex/Poseidon was within the accuracy of the Geosat measurements [35], that is, $10 \%$ or $0.5 \mathrm{~m}$, whichever is greater [36]. Topex/Poseidon was maneuvered into a 9.9156-day repeat period during which two pieces of Topex/Poseidon SWH data are available at each crossover point.

The Topex/Poseidon data was used to verify the accuracy of the WW3 simulations. The Topex/Poseidon satellite crossover points in the SCS in 2002 are shown in Figure 2.

The model SWH data were interpolated into all the crossover points where the hindcast and altimeter data were computed. Comparisons were conducted between the model hindcast results and the Topex/Poseidon altimeter observations. Synchronous comparisons of SWH are shown in Figures 4(a) and 4(b). The time series cover different 
periods in 2002 for all the crossover points as Topex/Poseidon passed over the SCS.

The skill of the model was evaluated through a conventional statistical analysis that consists in calculating the following:

$$
\begin{aligned}
\mathrm{CC} & =\frac{\sum_{i-1}^{n}\left(x_{i}-\bar{x}\right)\left(y_{i}-\bar{y}\right)}{\sqrt{\sum_{i-1}^{n}\left(x_{i}-\bar{x}\right)^{2} \sum_{i-1}^{n}\left(y_{i}-\bar{y}\right)^{2}}}, \\
\mathrm{Bias} & =\bar{y}-\bar{x}, \\
\mathrm{RMSE} & =\sqrt{\frac{1}{N} \sum_{i-1}^{n}\left(y_{i}-x_{i}\right)^{2},}
\end{aligned}
$$

where $x_{i}$ represents the observed data, $y_{i}$ represents the simulated data, $\bar{x}$ and $\bar{y}$ are mean values of observed and simulated data, and $N$ is the total number of observations.

As seen in Figure 4(b), the correlation coefficient (CC) between the simulated and observed data is 0.914 which indicates a close relationship between simulated and observed data. From Bias which is 0.012 , we find that the model slightly overestimates the observed SWH. The RMSE between the simulated and observed data is 0.432 indicating a low error of simulated data.

The distributions of Bias, RMSE, and CC for the whole year (2002) are also shown (Figure 4(c)) to understand the spatial error variability.

The Bias varies from $-0.43 \mathrm{~m}$ at point $18\left(107.7^{\circ} \mathrm{E}, 20.59^{\circ} \mathrm{N}\right)$ to $0.36 \mathrm{~m}$ at point $7\left(114.8^{\circ} \mathrm{E}, 9.81^{\circ} \mathrm{N}\right)$. Positive Bias dominates the SCS. In the Gulf of Tonkin, point $19\left(107.7^{\circ} \mathrm{E}, 20.59^{\circ} \mathrm{N}\right)$, negative Bias is greater than $-0.4 \mathrm{~m}$ and a positive Bias larger than $0.32 \mathrm{~m}$ is found very close to Nansha Island, point 14 $\left(114.8^{\circ} \mathrm{E}, 9.81^{\circ} \mathrm{N}\right)$. The RMSE ranges between $0.28 \mathrm{~m}$ at point $18\left(107.7^{\circ} \mathrm{E}, 5.93^{\circ} \mathrm{N}\right)$ and $0.94 \mathrm{~m}$ at point $4\left(114.81^{\circ} \mathrm{E}, 17.19^{\circ} \mathrm{N}\right)$.

The RMSE of SWH is generally above $0.45 \mathrm{~m}$ in the central SCS and decreases southwards. The CC of SWH between modeled and Topex/Poseidon data in 2002 is larger than 0.8 almost everywhere in SCS except in the Gulf of Tonkin in which CC is less than 0.6. The CC range between 0.53 at point $19\left(107.7^{\circ} \mathrm{E}, 20.59^{\circ} \mathrm{N}\right)$ and 0.96 at point $4\left(114.81^{\circ} \mathrm{E}\right.$, $\left.17.19^{\circ} \mathrm{N}\right)$.

Presented in Figure 4(d) is the temporal error of the monthly mean Bias and RMSE averaged over all the crossover points in the SCS. The Bias varies from $-0.0147 \mathrm{~m}$ in April to $0.051 \mathrm{~m}$ in March which shows that WW3 has a very low Bias in predicting the SWH. The RMSE has a minimum value $(0.33 \mathrm{~m})$ in April and a maximum value $(0.496 \mathrm{~m})$ in December.

In general, the simulation results are consistent with the observations, which indicate that the WW3 can well reproduce the SWH and as well be a dependable model to simulate surface waves in the SCS.

2.3. Analysis Methods. The WW3 model has been set to output several parameters at 6-hour intervals for the 30-year hindcast. The WAM4 parameterization was used for input and dissipation. Out of the main output wave parameters, the mean SWH was used to investigate the spatiotemporal variability of extreme SWH in the SCS. Extreme SWH defined in this paper are the largest (99th percentile) SWH. Seasonal mean extreme SWH were determined by combining the December-January-February monthly mean for winter, March-April-May for spring, June-July-August for summer, and September-October-November for autumn. The 99th-percentile SWH were also averaged annually and monthly and identified as annual and monthly mean extreme SWH. Trends in annual, seasonal, and monthly mean 99thpercentile SWH were computed for each grid point of the SCS domain. The trend analysis of the year-grouped extreme SWH climate was made by the linear least square fitting of time series of $\mathrm{SWH}$, while the $p$ values were computed to determine the significance of the trend. Trends at $95 \%$ confidence ( $p$ value $<0.05$ ) were considered statistically significant. The same analysis was also done for the mean SWH in the computation domain just to compare results (although they may slightly differ) with that of [31] that used the Tolman-Chalikov (TC) parameterization in the simulation. The wave direction climate and the spatiotemporal trends in peak wave period (Tp) in the SCS were also analyzed. Analysis is made if there are significant trends in the 100year return period estimate of 99th-percentile wave height by subdividing the annual mean 99th-percentile SWH into sections of 4-year period with extreme value analysis applied to each of the sections as done in a previous work by [32] using global altimeter data of wave height for a period greater than 20 years. Furthermore, linear trends in wave heights for the SCS are compared with other previous studies by $[4,17,28-30]$.

\section{Results and Discussion}

The annual spatial distribution of wave direction in the SCS is presented in Figure 3(a). Along a diagonal line crossing the SCS from southwest to northeast, the dominant wave direction is southwestwards. It is in the south southwestward direction in the southeast SCS and west southwestward in the northwest SCS.

Shown in Figure 3(b) is the seasonal distribution of the dominant wave direction in the SCS. During winter, the wave direction is southwestward in most parts of the SCS. In the spring and along a diagonal line running through the SCS from southwest to northeast, the wave is in a southwestward direction. In the southeast SCS, the wave is in a south southwestward direction and westward in most parts of northwest SCS. During summer, the wave direction is northeastward along the southwest to northeast diagonal line. It is in the eastward direction in the southeastern part of the SCS and north northeastward in the northwest SCS. During autumn, the wave is in the southwestward direction both along the southwest to northeast axis of SCS and in the northwestern part of SCS. It is in the south southwestward direction in southeast SCS.

In terms of the long-term trends in the annual mean SWH (Figure 5(a)), positive trends between 0.004 and $0.01 \mathrm{~m} \mathrm{yr}^{-1}$ dominate the central and northern SCS. The trends are particularly strongest $\left(0.01 \mathrm{~m} \mathrm{yr}^{-1}\right)$ around Luzon strait in the northern SCS down to Luzon in the eastern corner of 


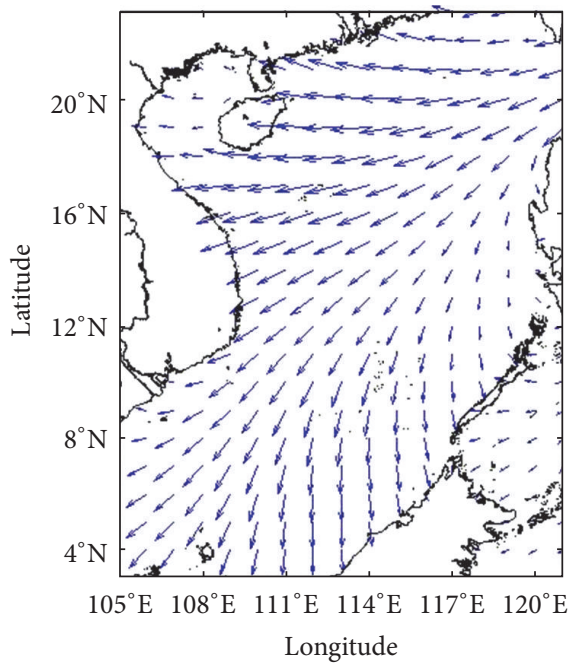

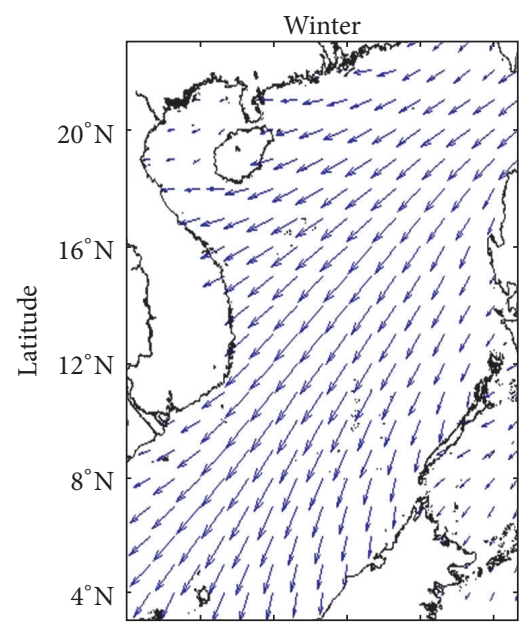

$105^{\circ} \mathrm{E} 108^{\circ} \mathrm{E} 111^{\circ} \mathrm{E} 114^{\circ} \mathrm{E} 117^{\circ} \mathrm{E} 120^{\circ} \mathrm{E}$ Longitude

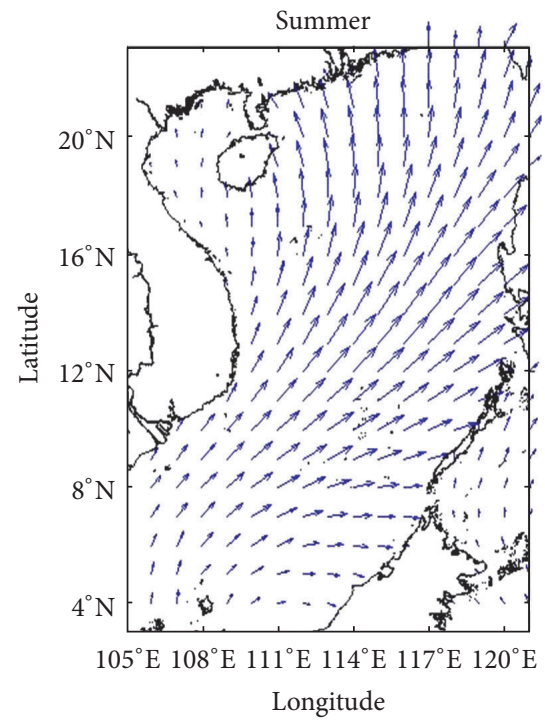

(a)
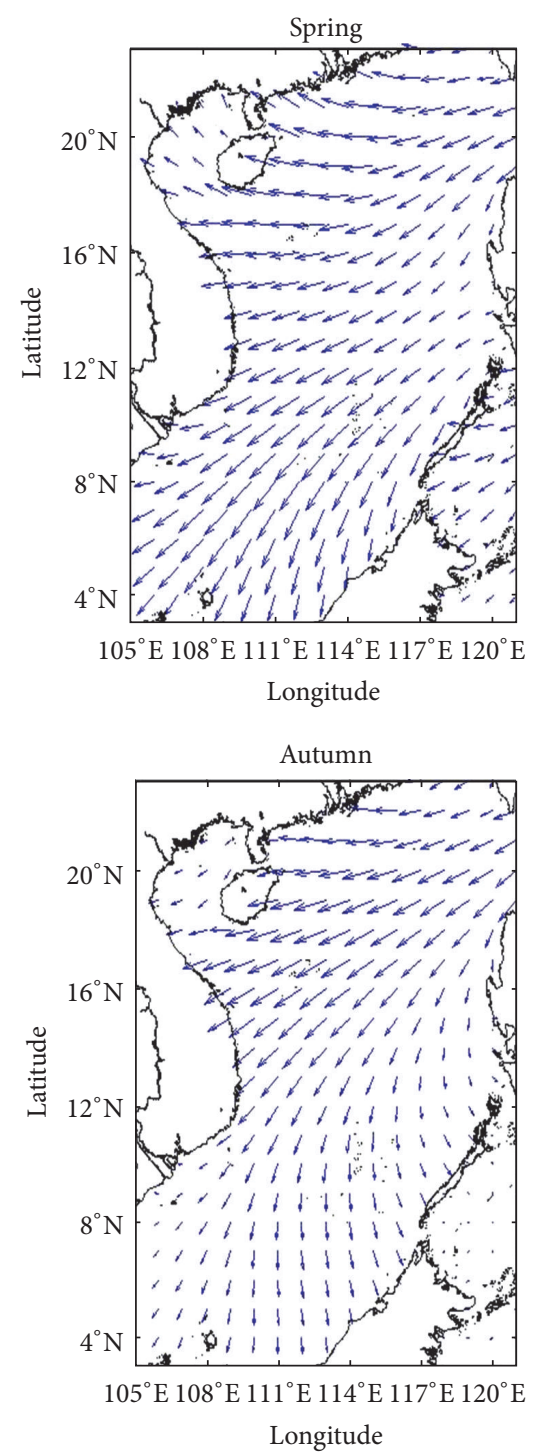

(b)

FIgURE 3: (a) Annual distribution of wave direction in the SCS. (b) Seasonal distribution of wave direction in the SCS. 


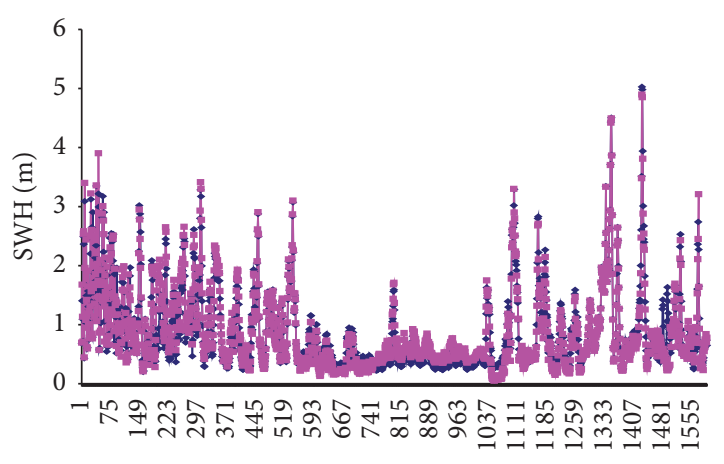

Number of points

- Observations

- Simulations

(a)

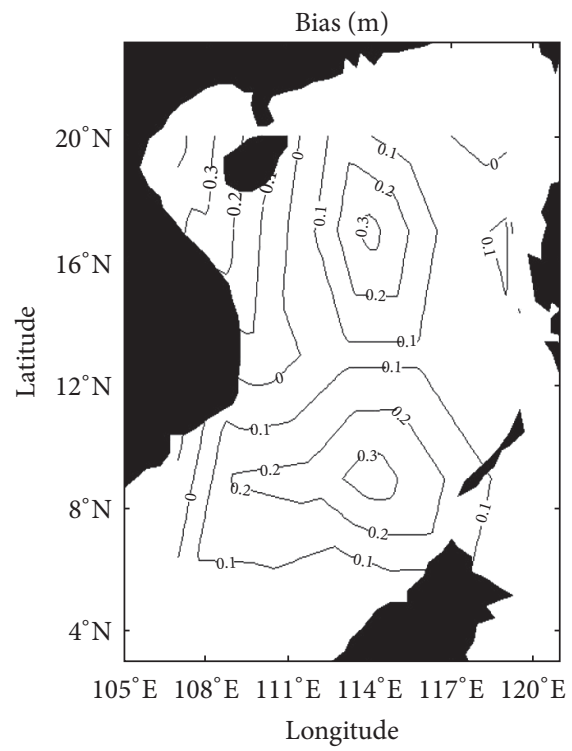

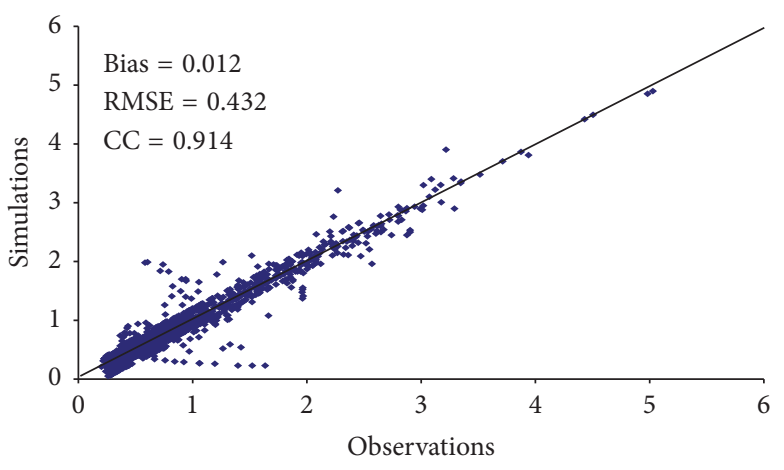

(b)

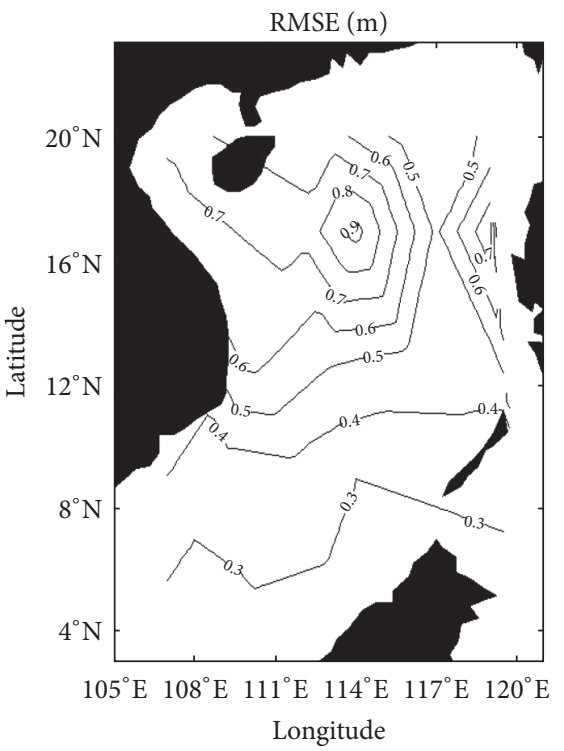

(c)

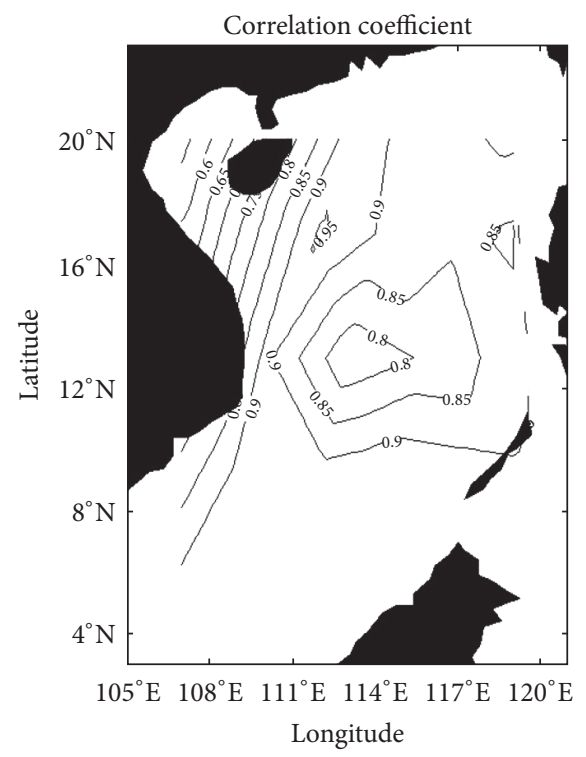

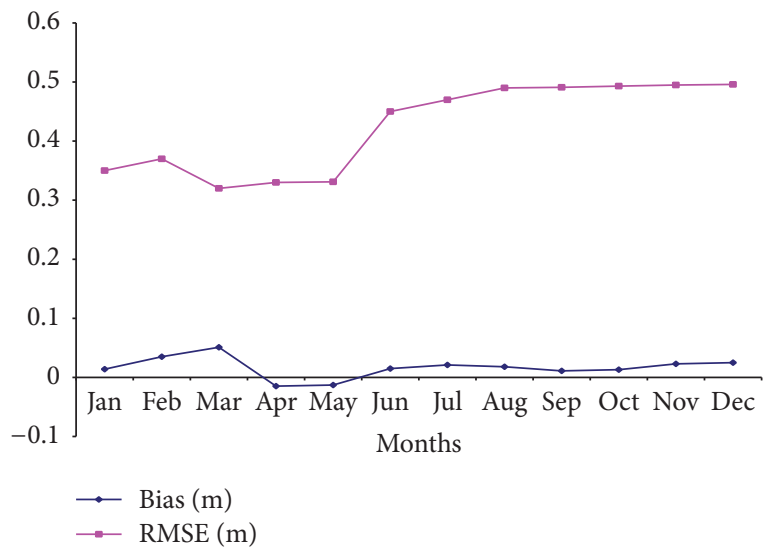

(d)

FIgURE 4: (a) Time series of the wave model data against Topex/Poseidon data for the SWH; on the $x$-axis is the number of data points. (b) Scatter plot of the wave model data against Topex/Poseidon data for the SWH. (c) Distributions of SWH: Bias, RMSE error, and correlation coefficient between WW3 and Topex/Poseidon data. (d) Temporal error variability of the Bias and RMSE between WW3 and Topex/Poseidon data for all the crossover points. 


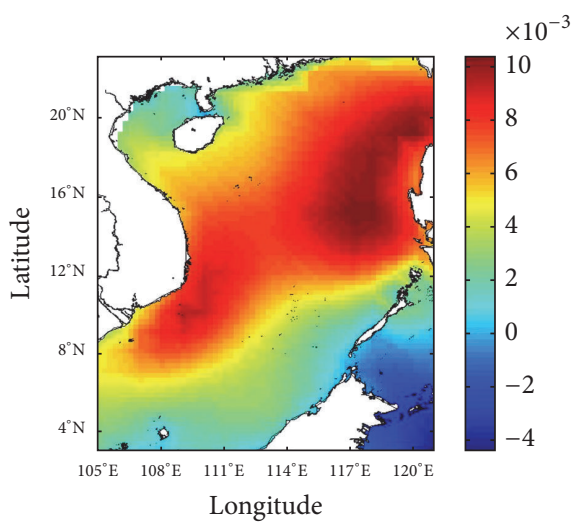

(a)
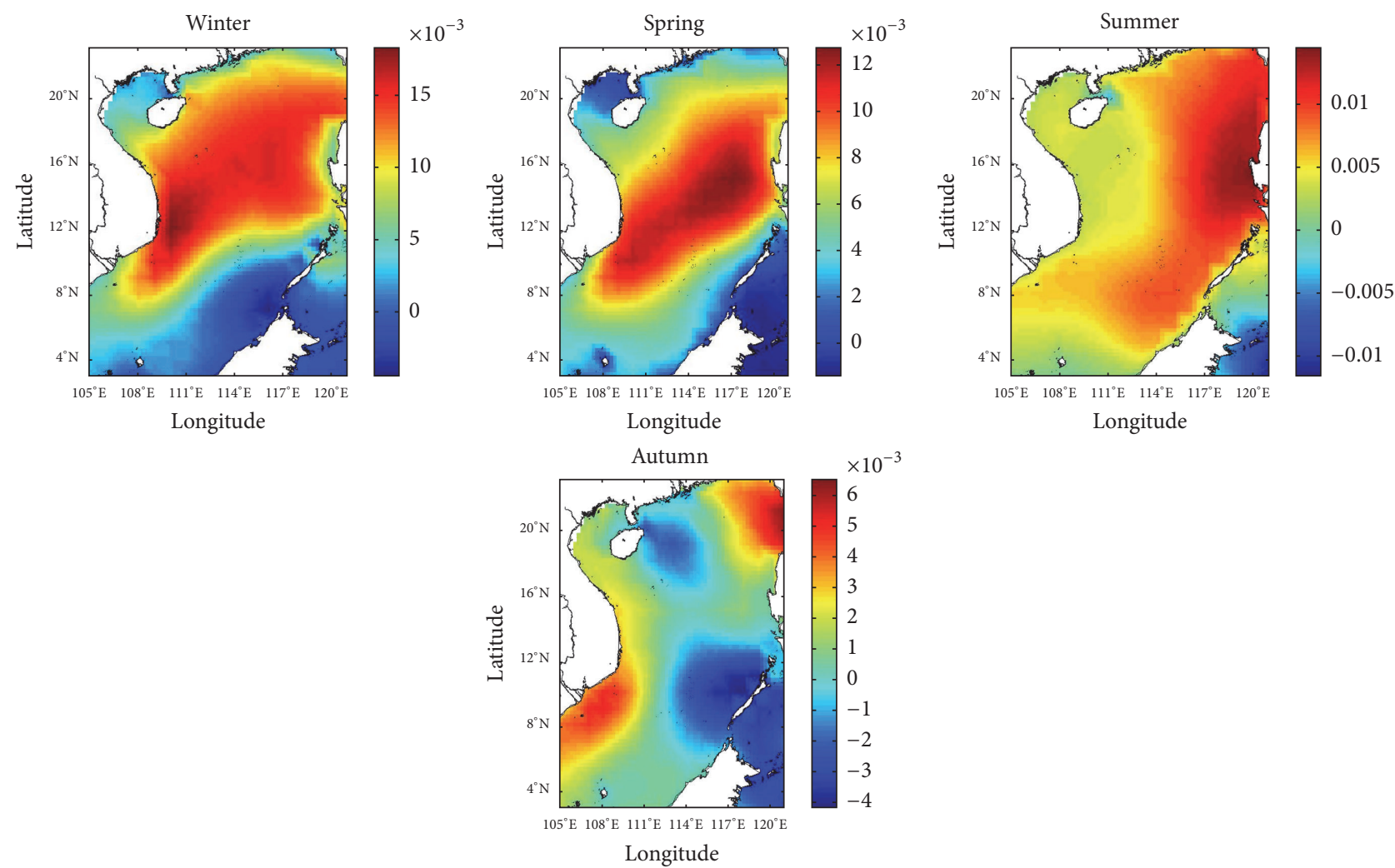

(b)
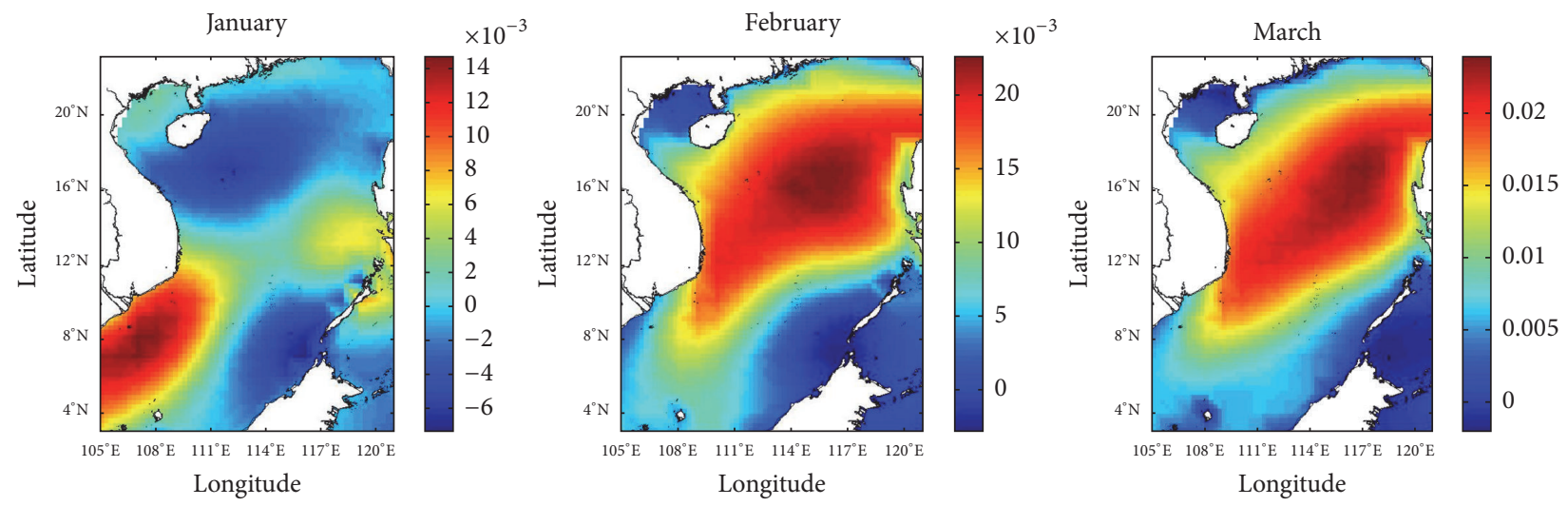

FIgURE 5: Continued. 

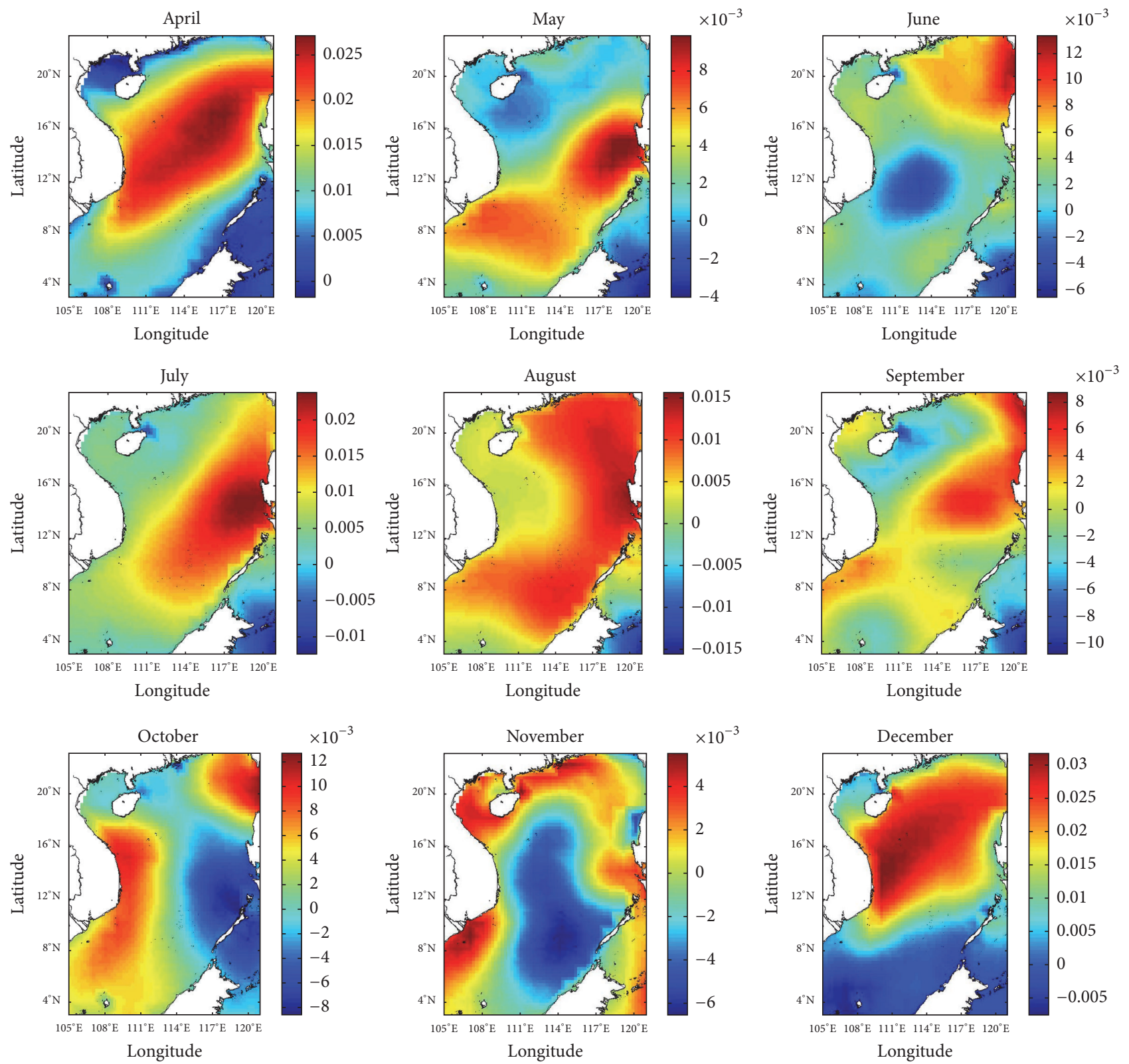

(c)

FIGURE 5: (a) Long-term trend of annual mean SWH from year 1976 to year 2005. Unit: $\mathrm{m} \mathrm{yr}^{-1}$. Only trends significant at the $95 \%$ level are shown. (b) Long-term trends of seasonal mean SWH from year 1976 to year 2005. Unit: $\mathrm{m} \mathrm{yr}^{-1}$. Only trends significant at the $95 \%$ level are shown. (c) Long-term trends of monthly mean SWH from year 1976 to year 2005. Unit: $\mathrm{m} \mathrm{yr}^{-1}$. Only trends significant at the $95 \%$ level are shown.

the central SCS. Strong trends are also noticed in Xisha and Zhongsha in the central SCS. Insignificant and decreasing trends $\left(<0.002 \mathrm{~m} \mathrm{yr}^{-1}\right)$ are observed to the upper left of Hainan island and in most regions of the Southern SCS.

The trends in seasonal mean SWH calculated for winter, spring, summer, and autumn are, respectively, shown in Figure 5(b).

In winter, the SWH in most waters of the SCS have an obvious increasing positive trend but are insignificant in regions surrounding Palawan in the southern SCS throughout the 30-year period. Areas with distinct increasing trends are mainly distributed in the central SCS $\left(0.015-0.020 \mathrm{~m} \mathrm{yr}^{-1}\right)$ around Xisha and Zhongsha.

During spring, increasing trends in SWH (0.01$0.014 \mathrm{~m} \mathrm{yr}^{-1}$ ) are centered around the central SCS and regions in the eastern axis of the SCS close to Luzon strait. They are insignificant $\left(0.002-0.006 \mathrm{~m} \mathrm{yr}^{-1}\right)$ in most parts of the southern SCS and in regions close to Taiwan and Hainan. 
Most waters of the SCS exhibit insignificant trends (0.003-0.007 $\left.\mathrm{m} \mathrm{yr}^{-1}\right)$ in SWH during summer but much more significant increasing trends $\left(0.01-0.02 \mathrm{~m} \mathrm{yr}^{-1}\right)$ are seen in areas around northeast SCS such as Taiwan and Luzon strait. Negative trends $\left(-0.001\right.$ to $\left.-0.01 \mathrm{~m} \mathrm{yr}^{-1}\right)$ are observed in the waters around Palawan.

Insignificant and negative SWH trends dominate most waters of the SCS during autumn. Waters with slight increasing trends (0.004-0.007 $\mathrm{m} \mathrm{yr}^{-1}$ ) are mainly located around Taiwan and regions south of Vietnam.

Figure 5(c) depicts the distribution of long-term trends in the monthly mean SWH. Generally, increasing positive trends of SWH (0.015-0.025 $\left.\mathrm{m} \mathrm{yr}^{-1}\right)$ are found to be significant in virtually all waters within the mid and higher latitudes of the SCS during February, March, and April. These trends $\left(0.002-0.025 \mathrm{~m} \mathrm{yr}^{-1}\right)$ are also found around the eastern central SCS during May, July, and September and over a vast portion of the SCS $\left(0.003-0.015 \mathrm{~m} \mathrm{yr}^{-1}\right)$ in August. In contrast, slight negative trends $\left(-0.001\right.$ to $\left.-0.005 \mathrm{~m} \mathrm{yr}^{-1}\right)$ dominate the southern region of the SCS during December and immediate regions $\left(-0.002\right.$ to $\left.-0.006 \mathrm{~m} \mathrm{yr}^{-1}\right)$ north and south of central SCS in November. These agree with the findings of [31]. Slight negative trends $\left(-0.002\right.$ to $\left.-0.006 \mathrm{~m} \mathrm{yr}^{-1}\right)$ in wave heights are also observed in regions southeast of Hainan islands and regions close to Palawan in January. Moreover, these trends are seen in June and October, respectively, in the central SCS.

Figures 6(a) and 6(b) show the temporal trends in the annual and seasonal mean SWH. By using the method of linear regression, which passes the reliability test of $95 \%$, the regression coefficient in Figure 6(a) is 0.0049. This means that the SWH exhibits an insignificant trend of $0.0049 \mathrm{~m} \mathrm{yr}^{-1}$ in the SCS as a whole throughout the 30-year period. From 1976 to 1985 , there is a small variation in SWH with annual average value of about $1.1 \mathrm{~m}$ and hence a slow changing trend of SWH; the SWH is between $1.04 \mathrm{~m}$ and $1.17 \mathrm{~m}$. In 1986, the SWH is about $1.32 \mathrm{~m}$, which is the maximum value within the 30 -year period. From 1986 to 1987, the SWH decreased remarkably from $1.32 \mathrm{~m}$ to $1.08 \mathrm{~m}$. SWH increased from $1.08 \mathrm{~m}$ in 1987 to $1.22 \mathrm{~m}$ in 1988 and the changing trend became slow again from 1988 to 1996 in which the SWH is between $1.13 \mathrm{~m}$ and $1.23 \mathrm{~m}$. The decreasing trend of SWH from $1.21 \mathrm{~m}$ to $0.97 \mathrm{~m}$ is obvious between 1996 and 1998 with 1998 having the least value of $0.97 \mathrm{~m}$ in the whole 30 years. This is due to a strong El Niño phenomenon between these years accompanying the weakening of the East-Asian Monsoon. The significant increase in SWH from $0.97 \mathrm{~m}$ in 1998 to $1.27 \mathrm{~m}$ in 1999 is due to a strong La Niña phenomenon accompanying the strengthening of East-Asian Monsoon [37]. The trend became slow again in 2005 .

In Figure 6(b), the SWH exhibits an increase of $0.0076 \mathrm{~m} \mathrm{yr}^{-1}$ in winter, $0.006 \mathrm{~m} \mathrm{yr}^{-1}$ in spring, $0.0056 \mathrm{~m} \mathrm{yr}^{-1}$ in summer, and $0.00044 \mathrm{~m} \mathrm{yr}^{-1}$ in autumn. Throughout the study period, the maximum value of SWH $(2.18 \mathrm{~m})$ in winter is noticed in 1999 while a minimum value $(1.35 \mathrm{~m})$ is noticed in 1979. In spring, maximum values of $0.93 \mathrm{~m}$ are seen in 2003 and 2005, whereas minimum values of $0.6 \mathrm{~m}, 0.61 \mathrm{~m}$, $0.61 \mathrm{~m}, 0.62 \mathrm{~m}, 0.59 \mathrm{~m}$, and $0.58 \mathrm{~m}$ are, respectively, seen in 1978, 1979, 1983, 1984, 1987, and 1992. During summer, a maximum value of $1.23 \mathrm{~m}$ is observed in 2002 while a minimum value of $0.45 \mathrm{~m}$ is observed in 1998 and, lastly, in the autumn, maximum values of $1.46 \mathrm{~m}$ and $1.48 \mathrm{~m}$ are, respectively, noticed in 1988 and 1992 while minimum values of $0.93 \mathrm{~m}$ are both noticed in 1988 and 1992. In general, the increase in the SCS SWH is strongest in winter, followed by spring, summer, and autumn.

The spatial trends of the annual and seasonal mean peak wave period are displayed in Figures 7(a) and 7(b). As shown in Figure 7(a), positive trends in peak wave period are distributed over virtually all parts of SCS. Significant positive trends (0.01-0.014 $\left.\mathrm{s} \mathrm{yr}^{-1}\right)$ are distributed mainly around the central SCS and in some islands such as Hainan and Dongsha in the northern SCS. The trends are insignificant around Tonkin Gulf in the northern SCS and around Kalimantan and Palawan in the southern SCS.

Figure 7 (b) shows that positive trends in peak wave period dominate most parts of the SCS during winter. The trends $\left(0.015-0.025 \mathrm{~s} \mathrm{yr}^{-1}\right)$ are particularly strongest over a large part of the southern SCS. Strong positive trends are also seen in small regions in the northern SCS. Insignificant trends are seen over some islands in the southern SCS and around Tonkin Gulf in the northern SCS.

During spring, strong positive trends (0.013-0.015 $\left.\mathrm{s} \mathrm{yr}^{-1}\right)$ occupy most parts of the southern SCS and a large portion of the northern SCS. Less significant trends are common in the central SCS and in areas around Luzon strait and Tonkin Gulf in the northern SCS. The trends are also found to be insignificant around some islands in the southern SCS.

In summer, strong positive trends centered around most parts of the central SCS and a large part of the northern SCS extending from Luzon strait to Dongsha island and surrounding waters. The trends $\left(>0.012 \mathrm{~s} \mathrm{yr}^{-1}\right)$ are strongest close to Liyue bank in the central SCS. Negative trends are seen around Tonkin Gulf and Hainan island in the northern SCS and are insignificant in some other regions.

Positive trends dominate most parts of the northern SCS and a large part of the central SCS during autumn. The trends are insignificant in every part of the southern SCS and in small regions in the central and northern SCS.

The temporal trends of the annual and seasonal mean peak wave period are displayed in Figures 8(a) and 8(b).

As shown in Figure 8(a), the wave period has a nearly identical trend with the annual mean SWH shown in Figure 3(a). In Figure 8(a), the wave period exhibits an insignificant trend of $0.0065 \mathrm{~s} \mathrm{yr}^{-1}$ throughout the 30 years. From 1976 to 1985, there is a small variation in wave period with annual average value of about $5.54 \mathrm{~s}$ and hence a slow changing trend of wave period; the wave period is between $5.38 \mathrm{~s}$ and $5.68 \mathrm{~s}$. In 1986 , the wave period is about $5.89 \mathrm{~s}$, which is the maximum value in the 30 years considered. From 1986 to 1987 , the wave period decreased remarkably from $5.89 \mathrm{~s}$ to $5.47 \mathrm{~s}$. Wave period increased from $5.47 \mathrm{~s}$ in 1987 to $5.65 \mathrm{~s}$ in 1988 and the changing trend became slow again from 1988 to 1996 in which the wave period is between $5.52 \mathrm{~s}$ and $5.72 \mathrm{~s}$. The decreasing trend of wave period from $5.66 \mathrm{~s}$ to $5.21 \mathrm{~s}$ is obvious between 1996 and 1998 with 1998 having 


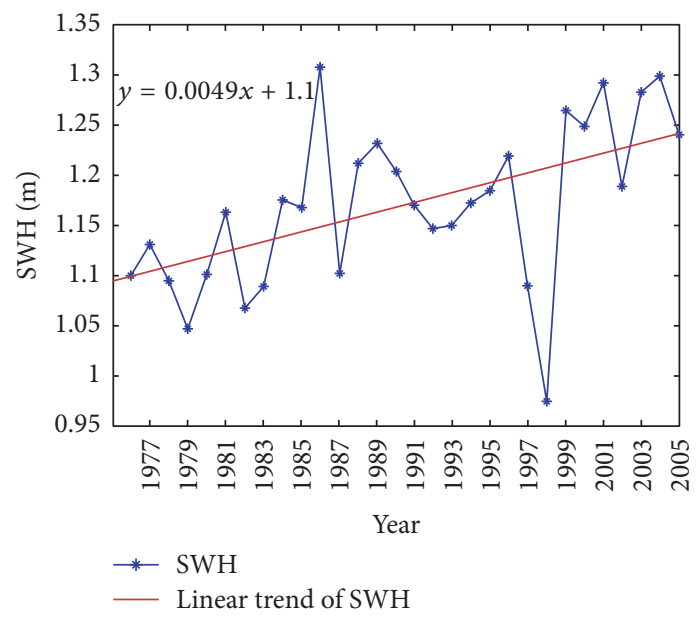

(a)
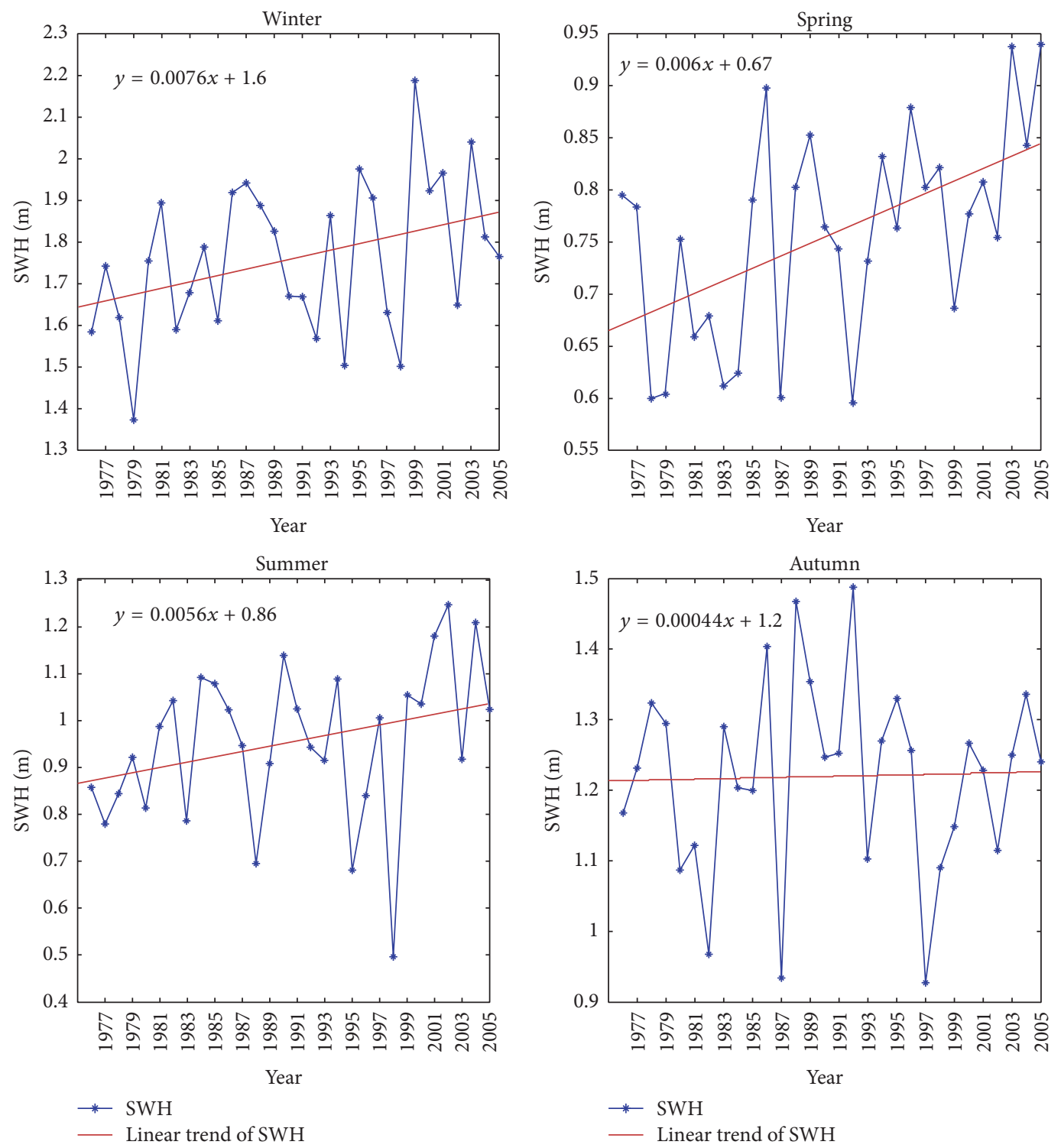

(b)

FiguRE 6: (a) Linear trend of annual mean SWH from year 1976 to year 2005. (b) Linear trends of seasonal mean SWH from year 1976 to year 2005. 


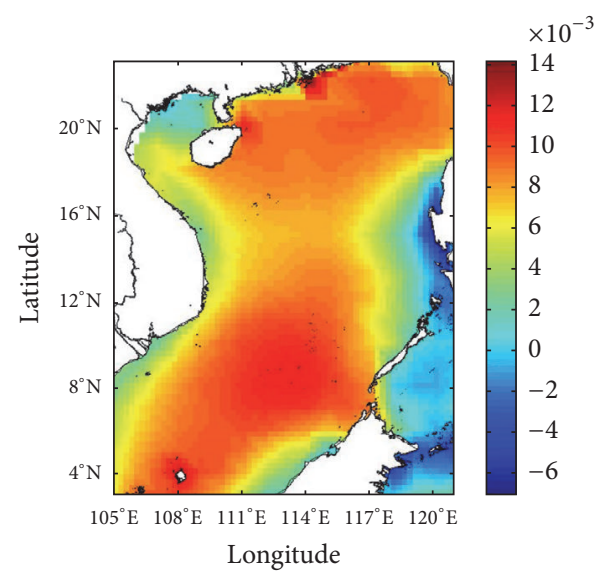

(a)
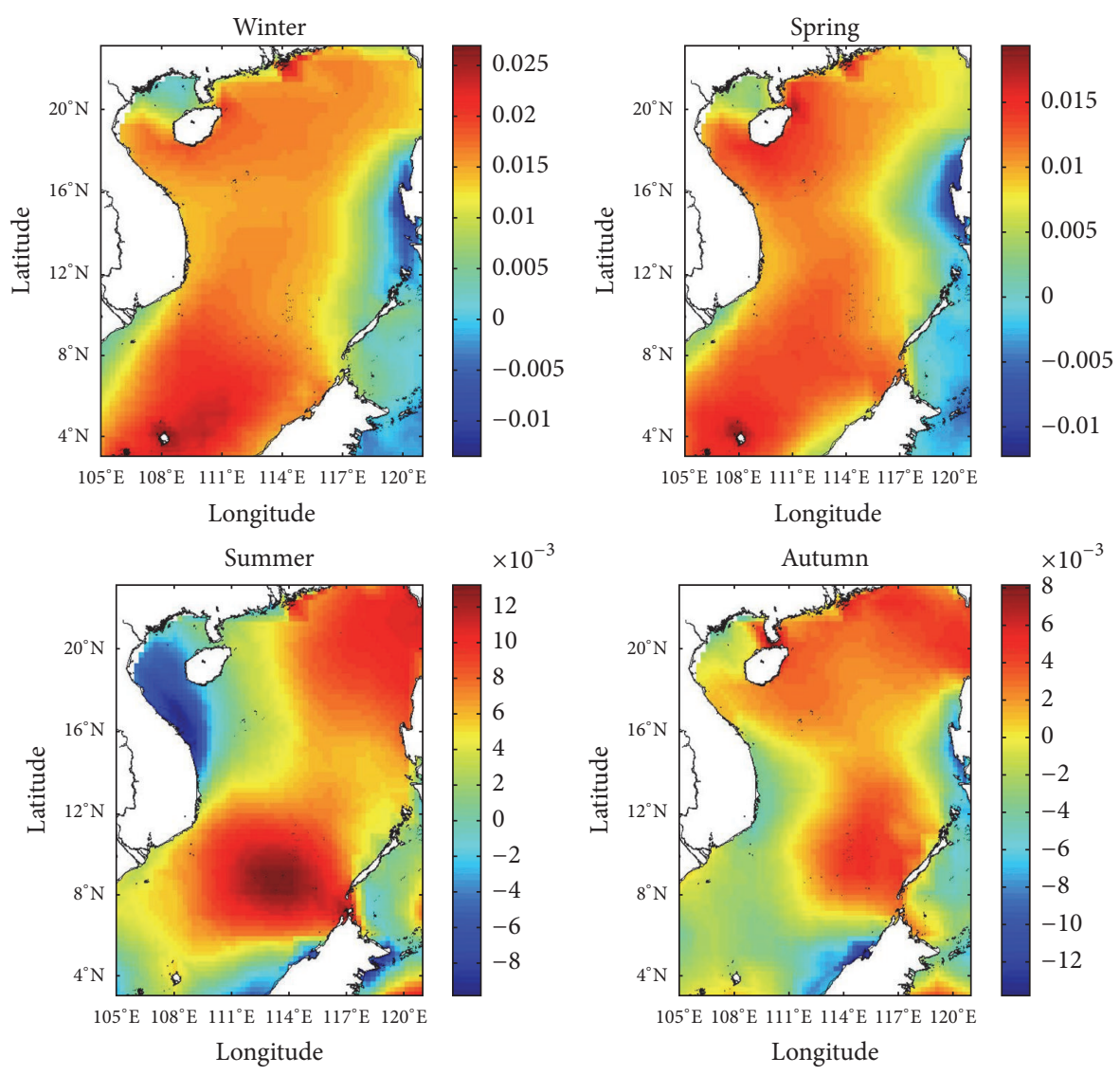

(b)

Figure 7: (a) Long-term trend of annual mean Tp from year 1976 to year 2005. Unit: $\mathrm{s} \mathrm{yr}^{-1}$. Only trends significant at the $95 \%$ level are shown. (b) Long-term trends of seasonal mean Tp from year 1976 to year 2005. Unit: $\mathrm{s} \mathrm{yr}^{-1}$. Only trends significant at the $95 \%$ level are shown.

the least value of $5.21 \mathrm{~s}$ during the last 30 years. This is also due to a strong El Niño phenomenon between these years accompanying the weakening of the East-Asian Monsoon. The significant increase in wave period from $5.21 \mathrm{~s}$ in 1998 to $5.85 \mathrm{~s}$ in 1999 is due to a strong La Niña phenomenon accompanying the strengthening of East-Asian Monsoon. The trend became slow again in 2005.

In Figure 8(b), the peak wave period exhibited a significant increase of $0.013 \mathrm{~s} \mathrm{yr}^{-1}$ during winter, $0.0082 \mathrm{~s} \mathrm{yr}^{-1}$ in spring, and $0.005 \mathrm{~s} \mathrm{yr}^{-1}$ in summer and a decreasing trend of $-0.000018 \mathrm{~s} \mathrm{yr}^{-1}$ in autumn. Throughout the 30 -year period, the maximum value of wave period $(6.98 \mathrm{~s})$ in the winter is noticed in 1999 while a minimum value $(5.68 \mathrm{~s})$ is noticed in 1979. In the spring, maximum values of $5.27 \mathrm{~s}$ and $5.26 \mathrm{~s}$ are found in 1996 and 2003, while minimum values of $4.74 \mathrm{~s}$, $4.61 \mathrm{~s}, 4.79 \mathrm{~s}, 4.61 \mathrm{~s}$, and $4.66 \mathrm{~s}$ are, respectively, observed in $1979,1983,1984,1987$, and 1992. During the summer, a maximum value of $5.69 \mathrm{~s}$ is observed in 2004 while a 


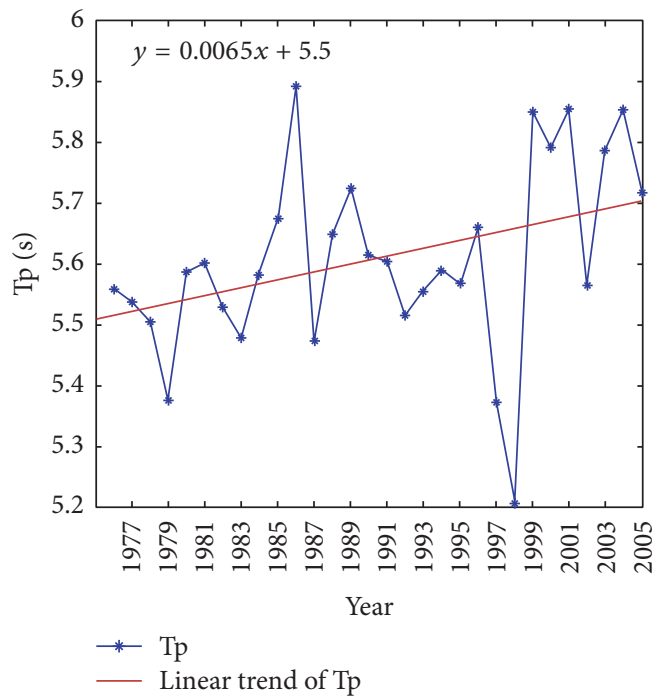

(a)
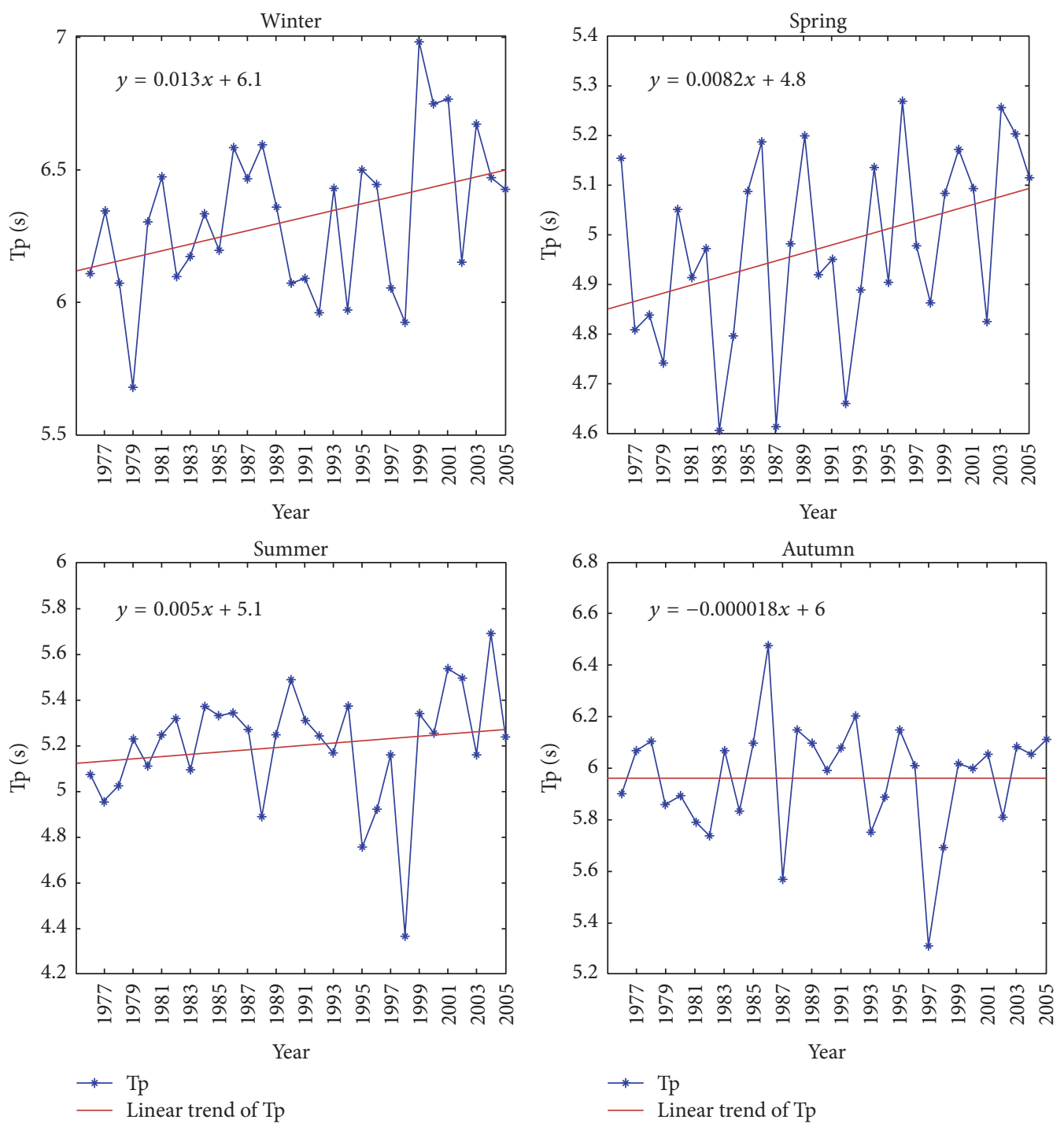

(b)

FIgURE 8: (a) Linear trend of annual mean Tp from year 1976 to year 2005. (b) Linear trends of seasonal mean Tp from year 1976 to year 2005. 
minimum value of $4.37 \mathrm{~s}$ is observed in 1998 and, lastly, in the autumn, a maximum value of $6.48 \mathrm{~s}$ is noticed in 1986 while a minimum value of $5.31 \mathrm{~s}$ is noticed in 1997. In general, the overall trend in the SCS peak wave period is only significant in winter. It is insignificant in spring and summer and negative in autumn.

The climatic variability of SWH was also based on the extreme (99th percentile) values on an annual, seasonal, and monthly basis (Figures 9(a)-9(c)). The extreme SWH in the SCS (Figure 9(a)) shows nonsignificant trends in the whole of the southern SCS and in some regions around Hainan island and Luzon strait in the northern SCS. Significant increasing trends $\left(0.05-0.1 \mathrm{~m} \mathrm{yr}^{-1}\right)$ are observed around Luzon and its west waters in the central SCS. Negative trends are found in Dongsha island and waters in the north central SCS.

A seasonal trend analysis (Figure 9(b)) shows that, during winter, positive trends in extreme SWH dominate virtually every part of the SCS. Insignificant trends are only noticed around some islands such as Kalimantan and Palawan in the southern SCS. Significant increasing trends (0.07$0.08 \mathrm{~m} \mathrm{yr}^{-1}$ ) are obvious around Luzon strait and adjacent waters in the northeast SCS. The increasing trends are less significant $\left(0.04-0.06 \mathrm{~m} \mathrm{yr}^{-1}\right)$ around Xisha and Zhongsha in the central part of the SCS.

Significant increasing trends $\left(>0.01 \mathrm{~m} \mathrm{yr}^{-1}\right)$ are distributed over a vast portion of the central SCS during spring. Strong negative trends are seen in Dongsha and Taiwan islands in the northern part of the SCS.

During summer, significant increasing trends (0.01$0.05 \mathrm{~m} \mathrm{yr}^{-1}$ ) are distributed over most parts of the central and southern SCS. Decreasing trends dominate the northern SCS and are most significant in a small region northeast of Hainan island.

During autumn, insignificant and negative trends dominate a large part of the SCS. Significant increasing trends $\left(0.02-0.08 \mathrm{~m} \mathrm{yr}^{-1}\right)$ are found in small regions in the central and northern SCS.

Also, from the monthly trend analysis (Figure 9(c)), increasing positive trends of extreme SWH are found to be generally significant in the central region of the SCS in December, February, March, and July. In contrast, significant negative trends of extreme SWH dominate the northern region of the SCS in January, June, and May. Significant negative trends of extreme SWH can also be found in October and November in the northern and central parts of SCS.

Insignificant trends dominate the southern SCS in July through November and also in March and April.

Regions where extreme waves have intensified since 1976 at a significant rate $\left(0.05-0.09 \mathrm{~m} \mathrm{yr}^{-1}\right)$ are locations such as Luzon strait in the northern SCS during October, Liyue bank and Gulf of Tonkin in the central and northern SCS during November, Dongsha islands in the northern SCS during August, Xisha and Luzon strait in the central and northern SCS during December, around Hainan island in the northern SCS during February, and close to Luzon in the central SCS during July.

Figures 10(a) and 10(b) show the temporal trends in the annual and seasonal mean extreme SWH. In Figure 10(a), the extreme SWH exhibits a significant increasing trend of $0.011 \mathrm{~m} \mathrm{yr}^{-1}$ in the SCS as a whole over the 30 -year period. From 1976 to 1990, there is a large variation in extreme SWH with annual average value of about $6.52 \mathrm{~m}$ and a significant increasing trend of $0.13 \mathrm{~m} \mathrm{yr}^{-1}$. The extreme SWH is between $5.14 \mathrm{~m}$ and $7.5 \mathrm{~m} .1990$ was the year of maximum value $(7.5 \mathrm{~m})$ of extreme SWH throughout the 30 -year period. An overall significant decreasing trend in extreme SWH $\left(-0.037 \mathrm{~m} \mathrm{yr}^{-1}\right)$ is noticed between 1990 and 2005. Prominent depressions in extreme SWH are noticed between 1990 and 1997 with the least value of $5.08 \mathrm{~m}$ in 1997 during the 30 -year period.

In Figure 10(b), the extreme SWH exhibits an overall trend of $0.03 \mathrm{~m} \mathrm{yr}^{-1}$ in winter, $0.0065 \mathrm{~m} \mathrm{yr}^{-1}$ in spring, $0.0055 \mathrm{~m} \mathrm{yr}^{-1}$ in summer, and $-0.0098 \mathrm{~m} \mathrm{yr}^{-1}$ in autumn. Throughout the 30-year period, the maximum value of extreme SWH $(6.15 \mathrm{~m})$ in winter is noticed in 1998 while a minimum value of $3.7 \mathrm{~m}$ is noticed in 1980. In spring, a maximum value of $5.2 \mathrm{~m}$ is noticed in 1989 and a minimum value of $1.8 \mathrm{~m}$ is seen in 1992. During summer, a maximum value of $5.74 \mathrm{~m}$ is observed in 1990 while a minimum value of $1.86 \mathrm{~m}$ is observed in 1998 and lastly, in autumn, a maximum value of $6.41 \mathrm{~m}$ is noticed in 1983 while minimum values of $3.54 \mathrm{~m}$ and $3.4 \mathrm{~m}$ are, respectively, seen in 1980 and 1992. In general, the overall increasing trend in extreme SWH is most significant in winter. It is insignificant in spring and summer and it exhibits a decreasing pattern in autumn.

Figure 11 presents the distribution of linear trends in 100year return period for the 99th-percentile wave height of the segments (periods). From the figure, it is seen that the trends are insignificant and negative (less than $0.3 \mathrm{~m} \mathrm{dec}^{-1}$ ) in most parts of SCS. The trends are only significant $\left(0.7 \mathrm{~m} \mathrm{dec}^{-1}-\right.$ $1.2 \mathrm{~m} \mathrm{dec}^{-1}$ ) in waters close to Liyue bank in the central SCS and Hainan island and Luzon strait in the northern SCS.

The temporal trends in 100-year return period, 99thpercentile wave height for each of the 4-year periods, are shown in Figures 12(a)-12(g). As can be seen, the linear trends are insignificant and negative in all the seven cases. These insignificant spatiotemporal trends in 100-year return period of the extreme wave heights for the seven periods for the SCS are comparable to a similar study by [32] in Young et al. investigation of trends in extreme value wave height using global altimeter data. The trends ranged between $-0.0402 \mathrm{~m} \mathrm{dec}^{-1}$ and $-0.0676 \mathrm{~m} \mathrm{dec}^{-1}$ for all the seven periods.

3.1. Comparison of Linear Trends in Significant Wave Heights with Some Other Previous Studies. The results of the longterm trends of extreme wave height in this study are also compared with a previous study by [4] in the Northeast Pacific from 26 buoys over the period 1985-2007. Regions in the SCS that have similar statistically significant positive trends $\left(0.02\right.$ to $0.04 \mathrm{~m} \mathrm{yr}^{-1}$ ) as most locations along the California coast are waters surrounding Natuna around the southwest corner of the SCS and waters along the Vietnam border and close to Hainan island in northwest SCS and in some few regions around Taiwan strait, Taiwan, and Luzon strait in northeast SCS. Regions south of latitude $12^{\circ} \mathrm{N}$ in the SCS such as Nansha, Sulu sea, Borneo, Kalimantan, and 


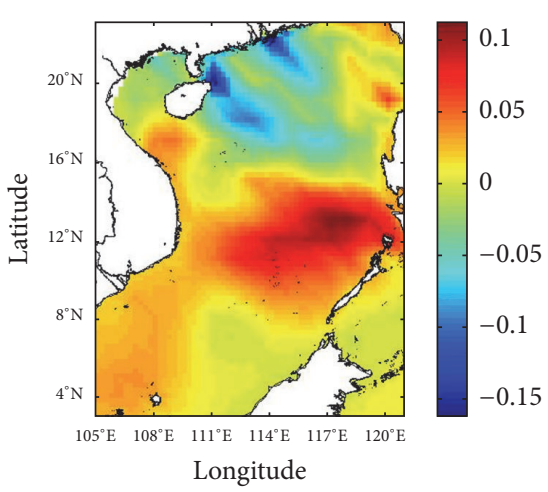

(a)
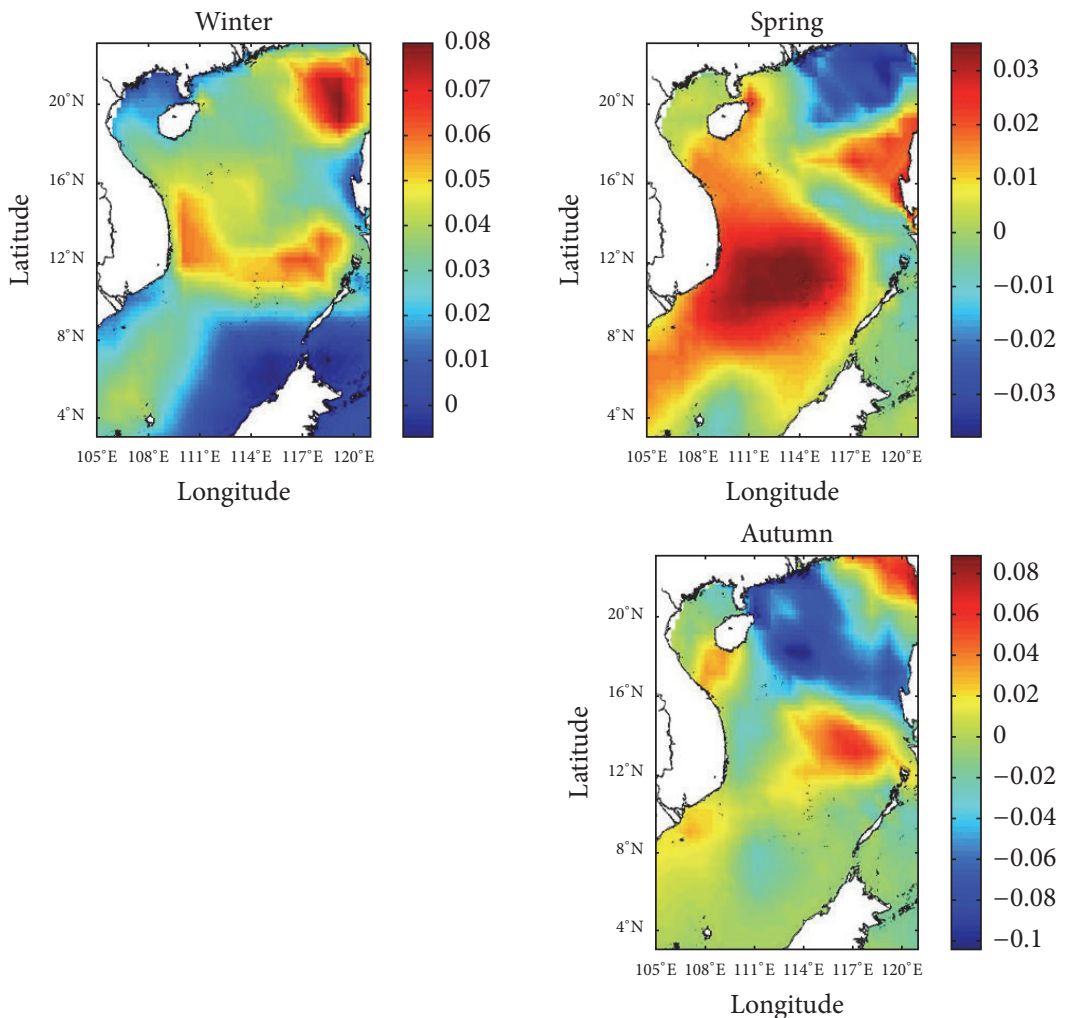

(b)

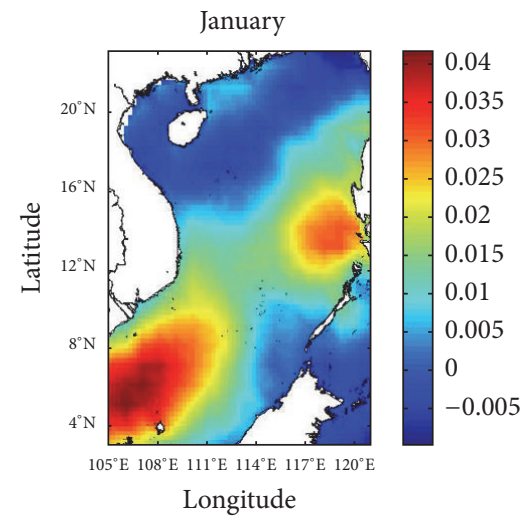

February

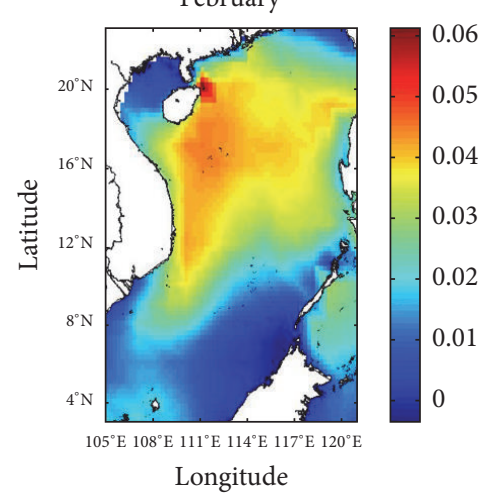

FIgure 9: Continued.

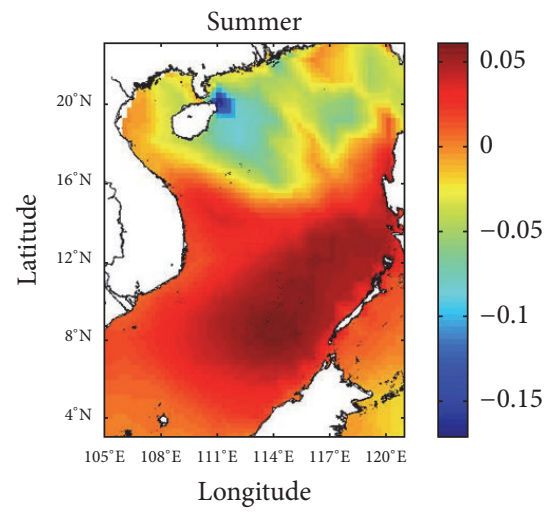

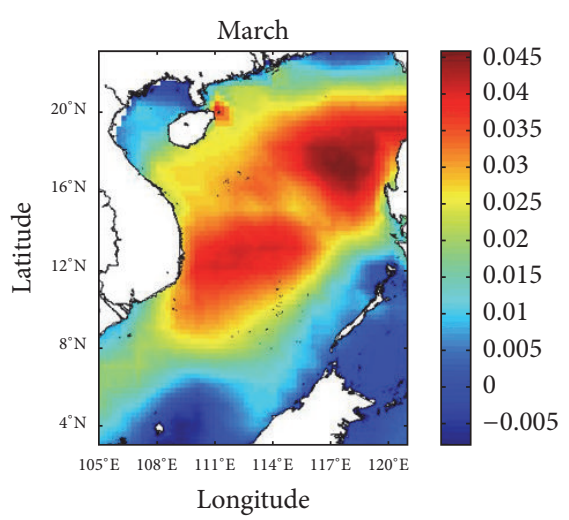



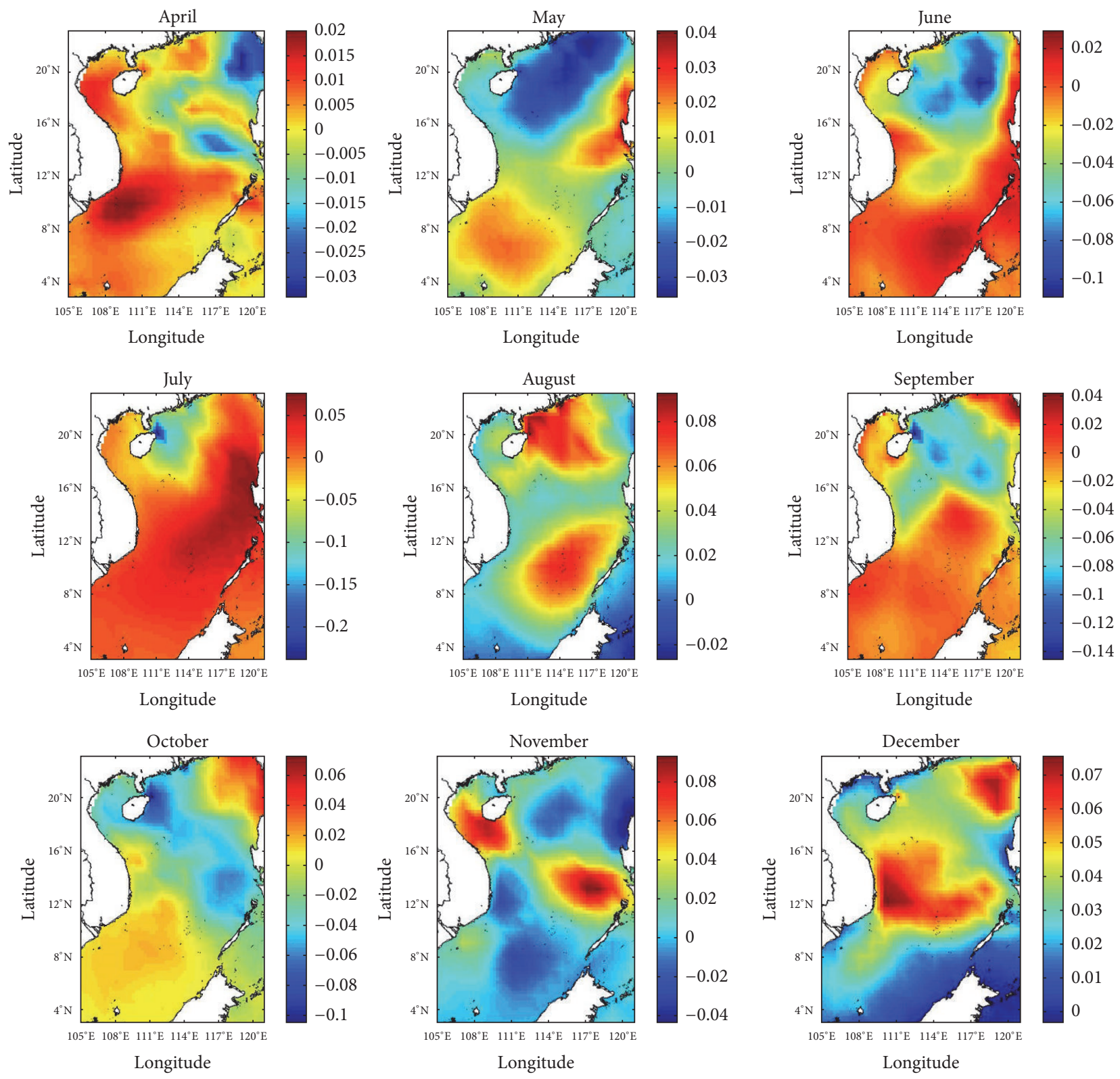

(c)

FIGURE 9: (a) Long-term trend of annual mean 99th-percentile SWH from year 1976 to year 2005. Unit: $\mathrm{m} \mathrm{yr}^{-1}$. Only trends significant at the 95\% level are shown. (b) Long-term trends of seasonal mean 99th-percentile SWH from year 1976 to year 2005. Unit: $\mathrm{m} \mathrm{yr}^{-1}$. Only trends significant at the $95 \%$ level are shown. (c) Long-term trends of monthly mean 99th-percentile SWH from year 1976 to year 2005 . Unit: $\mathrm{m}$ yr ${ }^{-1}$. Only trends significant at the $95 \%$ level are shown.

Palawan with few waters in the northern SCS exhibit small and no significant trends ( 0 to $0.01 \mathrm{~m} \mathrm{yr}^{-1}$ ) similar to buoys around Alaska and Hawaiian islands. Decreasing trends are distributed in most waters above $15^{\circ} \mathrm{N}$ in the SCS like that observed from some Canadian buoys in the Northeast Pacific.

In a spatiotemporal analysis of seasonality, strong spatial trends in extreme wave height ranging between 0 and $0.07 \mathrm{~m} \mathrm{yr}^{-1}$ exist in winter months of December and February. Temporal analysis also showed that strong trends exist in December $\left(0.033 \mathrm{~m} \mathrm{yr}^{-1}\right)$ and February $\left(0.023 \mathrm{~m} \mathrm{yr}^{-1}\right)$. This is comparable to the severity of extreme wave height in the Northeast Pacific and Bering Sea between October and March (Boreal Winter).

As the SCS lies in a tropical location, a comparison of trends in the annual mean significant wave height from simulations over the SCS (a region in the west north pacific) with that of buoy and altimeter measurements over 5 points in the north pacific within $40.9-57.1^{\circ} \mathrm{N}$ and $130.5-177.8^{\circ} \mathrm{E}$ showed that the trend in annual mean wave height is weaker $\left(-4\right.$ to $\left.0.01 \mathrm{~m} \mathrm{yr}^{-1}\right)$ in the SCS than that from buoy $(-0.0045$ 


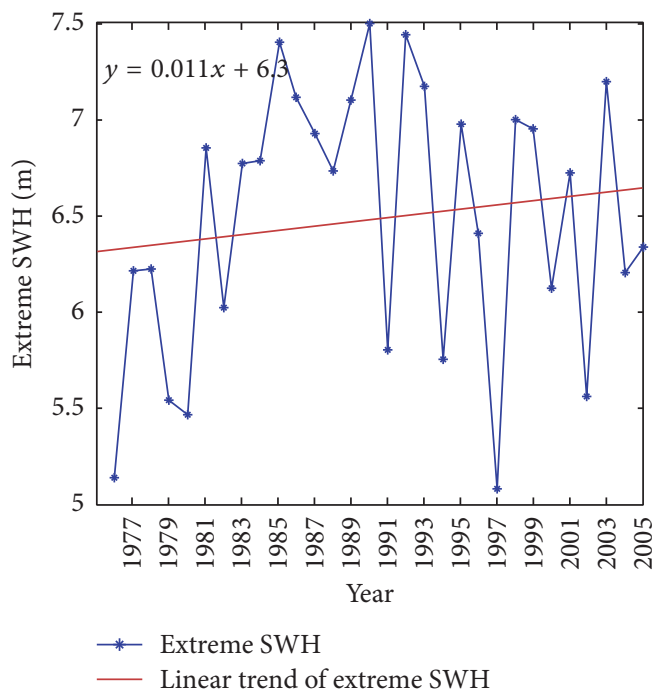

(a)
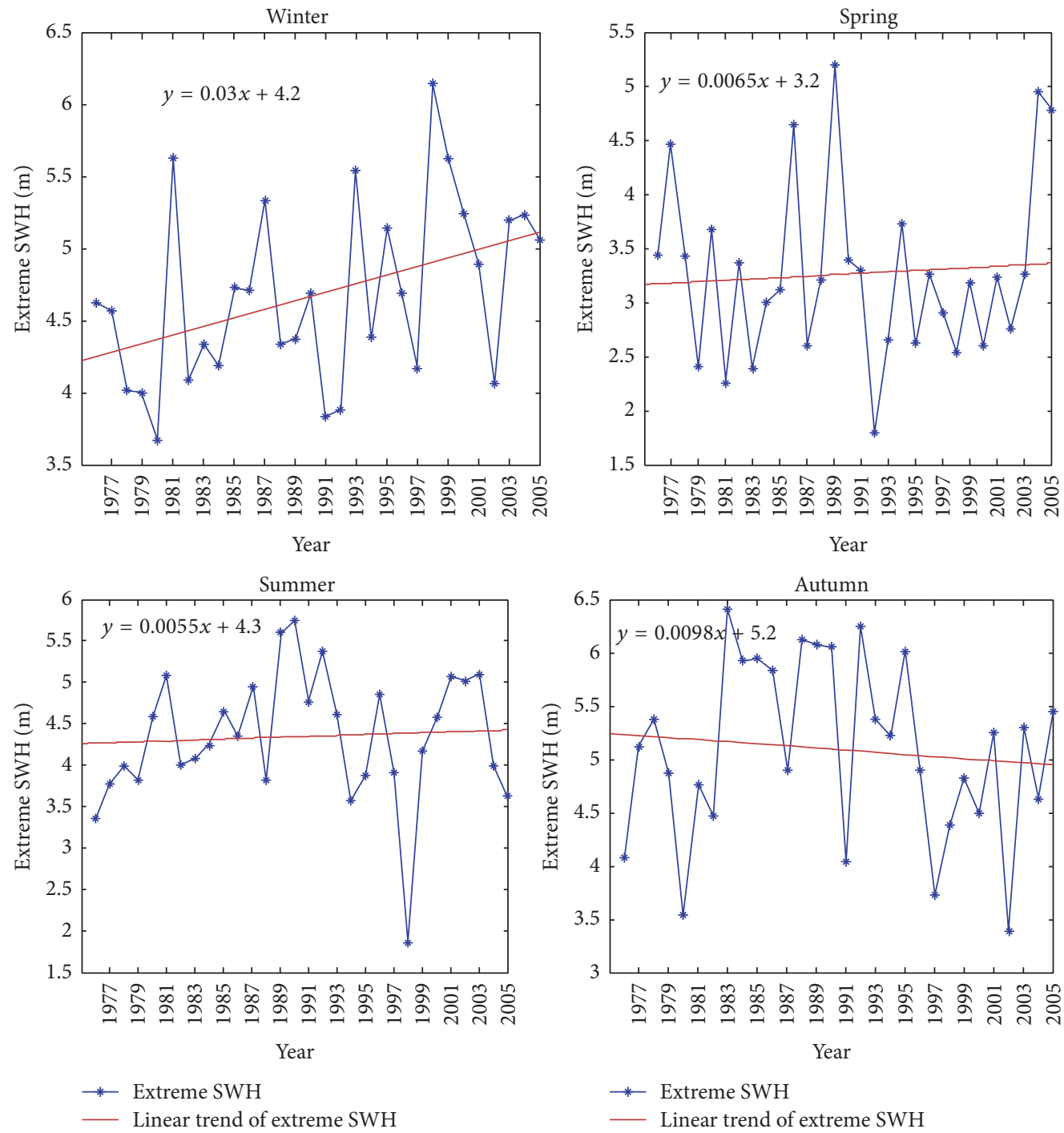

(b)

FIGURE 10: (a) Linear trend of annual mean 99th-percentile SWH from year 1976 to year 2005. (b) Linear trends of seasonal mean 99thpercentile SWH from year 1976 to year 2005. 


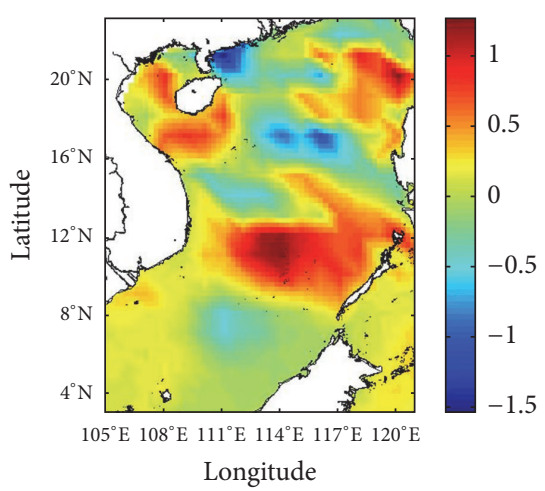

FIGURE 11: Spatial trend in 100-year return period, 99th-percentile wave height calculated using linear regression from the extreme value analysis of the segments (periods) for the SCS. Note. The values on the side bar are in $\mathrm{m} \mathrm{decade}^{-1}$.

to $\left.0.0098 \mathrm{~m} \mathrm{yr}^{-1}\right)$ and altimeter $\left(-0.0036\right.$ to $\left.0.0042 \mathrm{~m} \mathrm{yr}^{-1}\right)$ measurement in the north pacific.

Also, a comparison of 99th-percentile trends in wave height between simulations in the SCS and buoy with altimeter measurements over the 5 locations in the north pacific showed that the trend is weaker $\left(-0.15\right.$ to $\left.0.1 \mathrm{~m} \mathrm{yr}^{-1}\right)$ in the SCS than that from buoy $\left(-0.0254\right.$ to $\left.0.0184 \mathrm{~m} \mathrm{yr}^{-1}\right)$ and altimeter $\left(0.0259\right.$ to $\left.0.045 \mathrm{~m} \mathrm{yr}^{-1}\right)$ in the north pacific. These comparisons are done in order to validate the trends observed from simulations and the above results are consistent with the findings of [17] in that the 99th-percentile wave height trends are progressively more positive with higher latitudes $\pm 35^{\circ}$ of the northern and southern hemisphere and also the equatorial and tropical regions of all oceanic basins show a neutral trend for wave height for the mean and 99thpercentile wave heights. The results of this study further confirmed the findings of [17] that wave height trend becomes more positive moving from the mean $\left(-4\right.$ to $\left.0.01 \mathrm{~m} \mathrm{yr}^{-1}\right)$ to the 99 th-percentile $\left(-0.15\right.$ to $\left.0.1 \mathrm{~m} \mathrm{yr}^{-1}\right)$ conditions. The nearneutral trends in both mean and 99th-percentile wave height in the SCS are a result of the wave climate in tropical waters which is dominated by remotely generated swell and results in most cases show little correlation between wind speed and wave height trends in the tropics.

The 25-year decadal trends in annual averages of the winter significant wave heights measured by US West Coast buoys at different latitudes as reported by [28] ranged between $0.006 \mathrm{~m} \mathrm{yr}^{-1}$ for Pt. Arguello and $0.032 \mathrm{~m} \mathrm{yr}^{-1}$ for Washington. The trend over Pt. Arguello $\left(0.006 \mathrm{~m} \mathrm{yr}^{-1}\right)$ from buoy 46023 compares better with the value $\left(0.0076 \mathrm{~m} \mathrm{yr}^{-1}\right)$ obtained during winter for the SCS than higher trends observed for Washington (buoy 46005), Oregon (buoy 46002), Pt. Arena (buoy 46014), and Half Moon Bay (buoy 46012) with respective trends of $0.032 \mathrm{~m} \mathrm{yr}^{-1}, 0.028 \mathrm{~m} \mathrm{yr}^{-1}$, $0.021 \mathrm{~m} \mathrm{yr}^{-1}$, and $0.012 \mathrm{~m} \mathrm{yr}^{-1}$ in the United States West Coast. The trends in extreme value wave height during winter between the SCS $\left(0.03 \mathrm{~m} \mathrm{yr}^{-1}\right)$ and Washington (buoy 46005) $\left(0.108 \mathrm{~m} \mathrm{yr}^{-1}\right)$ differed by $0.078 \mathrm{~m} \mathrm{yr}^{-1}$. Also, the trends in the annual average wave height between the SCS $\left(0.0049 \mathrm{~m} \mathrm{yr}^{-1}\right)$ and Washington (buoy 46005) (0.024 $\mathrm{m} \mathrm{yr}^{-1}$ ) differed by $0.0191 \mathrm{~m} \mathrm{yr}^{-1}$. The higher latitudinal position of Washington (buoy 46005) accounts for the large difference in trends from that of SCS.

A comparison of linear trends in the annual averages of the "winter" and "summer" significant wave heights over a 31-year period by three NDBC buoys which are buoys 44004East of Cape May, NJ, 41001-East of Cape Hatteras, NC, and 41002-East of Charleston, SC, all in the US East Coast [29] with the trends in the annual averages of the "winter" and "summer" significant wave heights obtained in this study showed that, in the SCS, winter exhibits a higher trend $\left(0.0076 \mathrm{~m} \mathrm{yr}^{-1}\right)$ in wave height than the trends obtained for the 3 Atlantic buoys (buoys 44004, 41001, and 41002) which are, respectively, $-0.002,0.001$, and $0.002 \mathrm{~m} \mathrm{yr}^{-1}$. On the other hand, during summer (hurricane season) in the US East Coast, each of the 3 respective buoys showed higher trends (0.011, 0.015 , and $\left.0.016 \mathrm{~m} \mathrm{yr}^{-1}\right)$ in wave height as compared with that of SCS $\left(0.0056 \mathrm{~m} \mathrm{yr}^{-1}\right)$ in summer.

The results of the long-term trends in the annual mean, winter average, and annual maximum wave height in this study are compared with a previous study by [30], using wave data gathered since mid-1970s in deep water over the US Pacific Northwest (Oregon and Washington), with buoy 46005 of NDBC. Higher trends in all cases are observed in the study of [30] than over the SCS. The differences in the trends in the annual mean, winter average, and annual maximum wave height are, respectively, 0.0101, 0.0154, and $0.084 \mathrm{~m} \mathrm{yr}^{-1}$. Furthermore, during summer (May through September), higher trends $\left(0.009 \mathrm{~m} \mathrm{yr}^{-1}\right)$ in annual average wave heights are observed in the US Pacific Northwest than that found during summer $\left(0.0056 \mathrm{~m} \mathrm{yr}^{-1}\right)$ in the SCS.

\section{Conclusion}

A 30-year wave simulation for the SCS based on highresolution reanalysis wind field data sets is presented in this study. Statistical model-data validation using altimetry (Topex/Poseidon) wave information showed the model's capability to reproduce mean wave conditions in the SCS.

The work by [31] has been extended by investigating the long-term spatiotemporal trends in extreme significant wave heights in SCS.

Spatial trend analysis of extreme significant wave height showed that significant increasing trends $\left(0.05-0.1 \mathrm{~m} \mathrm{yr}^{-1}\right)$ are observed around Luzon and its west waters in the central SCS. During winter, strong positive trends $\left(0.07-0.08 \mathrm{~m} \mathrm{yr}^{-1}\right)$ are obvious around Luzon strait and adjacent waters in northeast SCS. Significant trends greater than $0.01 \mathrm{~m} \mathrm{yr}^{-1}$ are distributed over a large part of the central SCS during spring. In summer, significant increasing trends between 0.01 and $0.05 \mathrm{~m} \mathrm{yr}^{-1}$ are distributed over most parts of the central and southern SCS. During autumn, strong positive trends between 0.02 and $0.08 \mathrm{~m} \mathrm{yr}^{-1}$ are found in small regions in the central and northern SCS. Increasing positive trends in extreme significant wave height are found to be generally significant in the central region of the SCS in December, February, March, and July. 


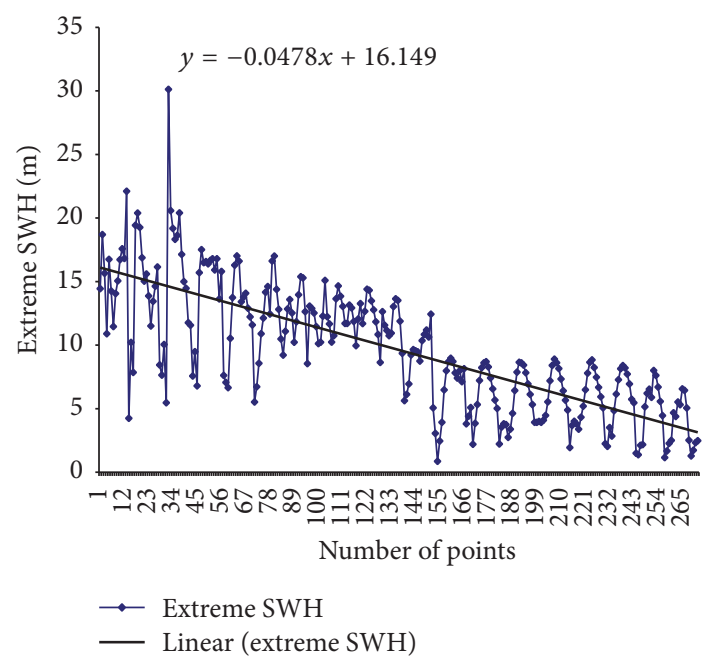

(a)

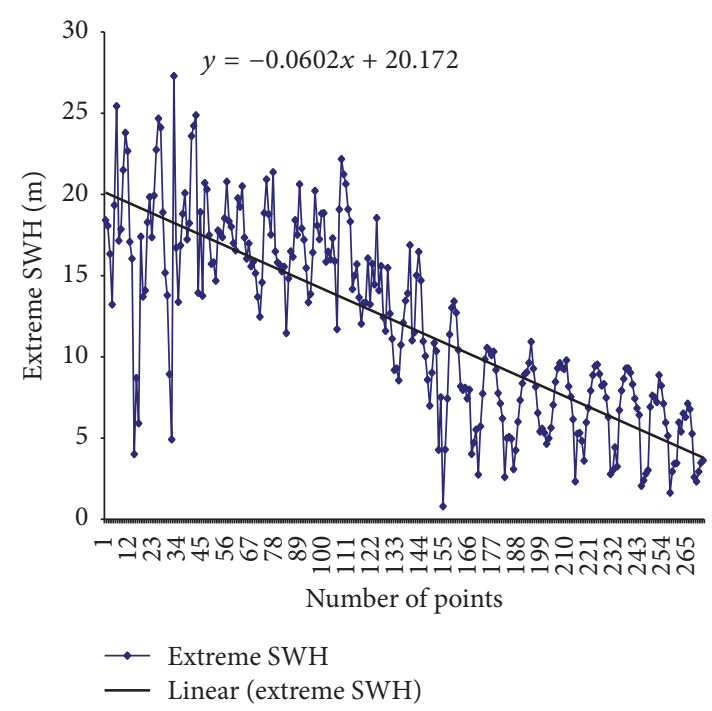

(c)

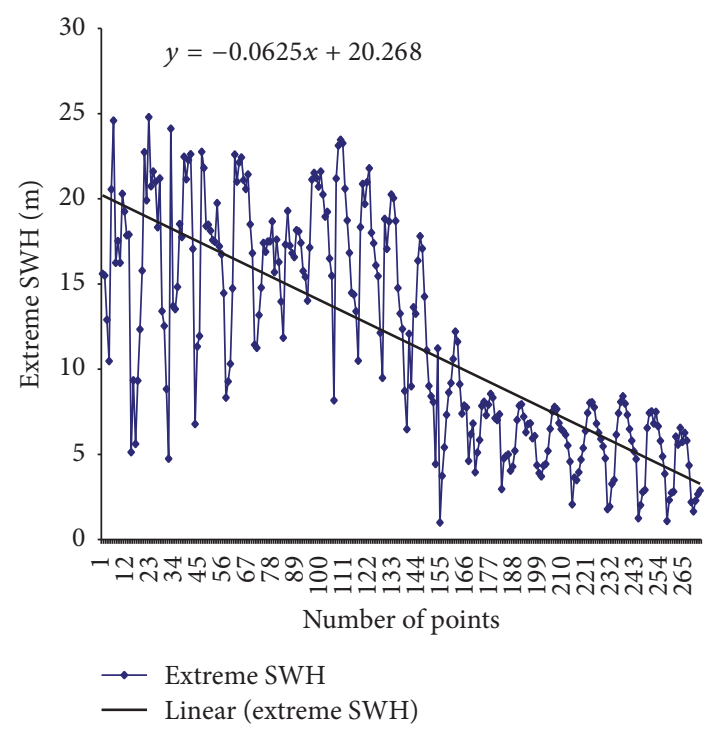

(e)

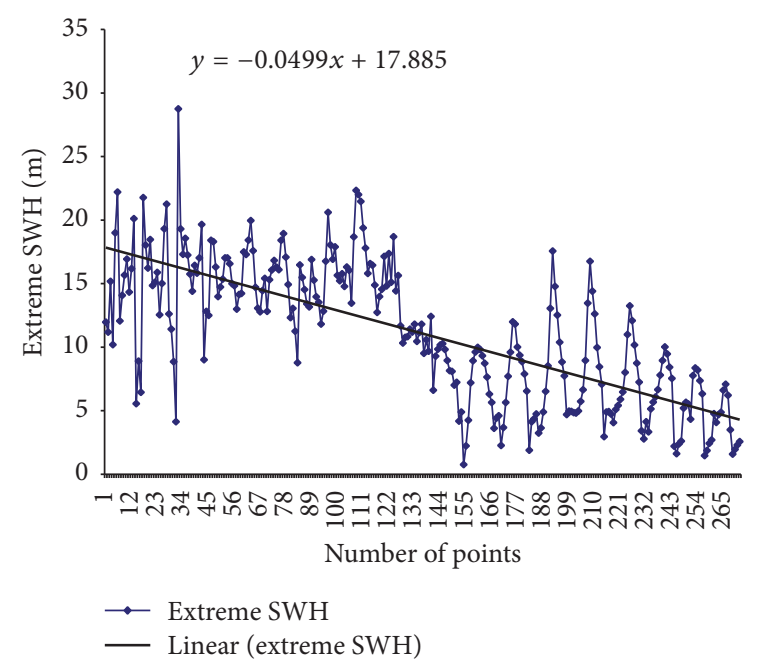

(b)

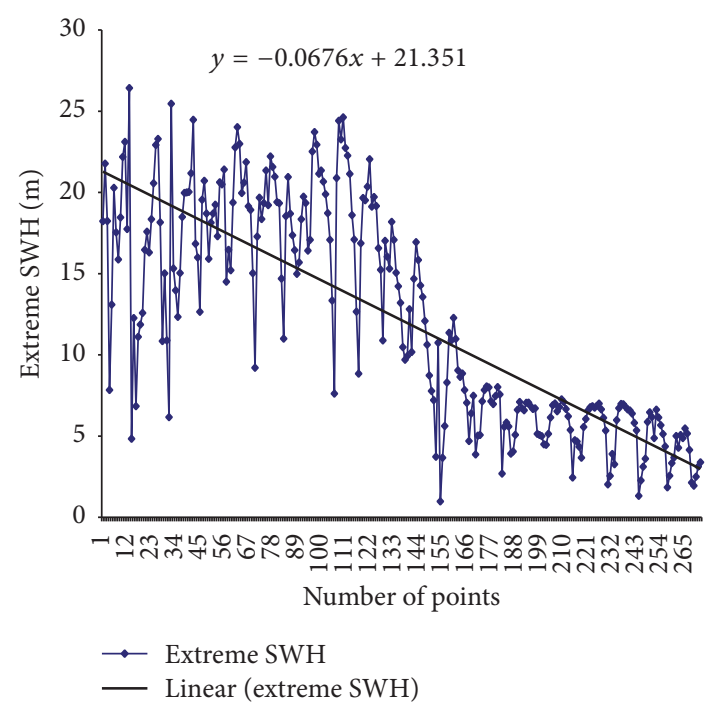

(d)

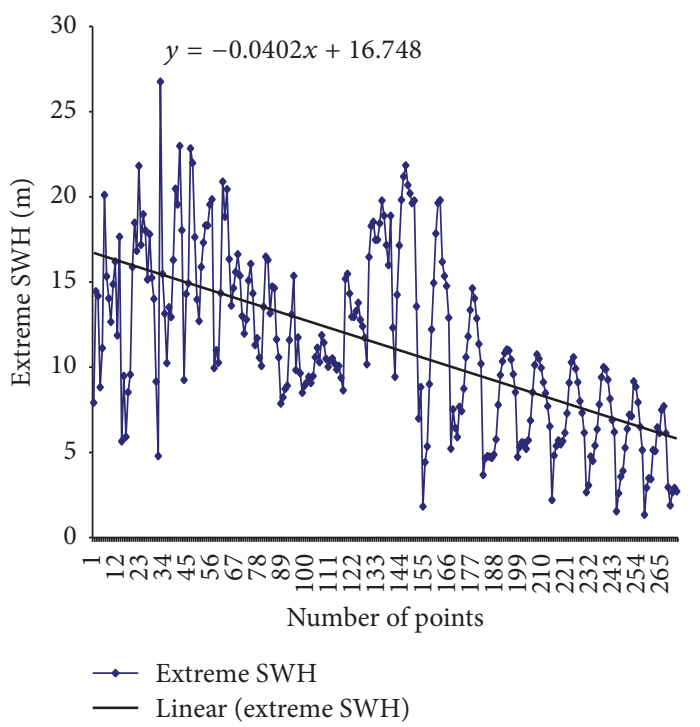

(f)

FIGURE 12: Continued. 


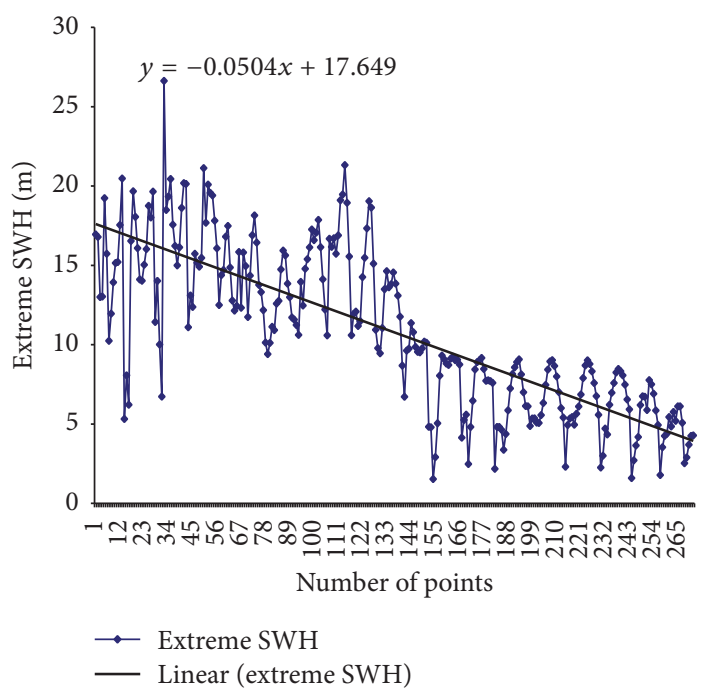

(g)

FIGURE 12: Temporal trends in 100-year return period, 99th-percentile wave height calculated using linear regression from the extreme value analysis of (a) 1976-1980, (b) 1980-1984, (c) 1984-1988, (d) 1988-1992, (e) 1992-1996, (f) 1996-2000, and (g) 2000-2005 segments (periods) for the SCS.

Also, temporal trend analysis of extreme significant wave height in the SCS showed that the extreme SWH exhibits a significant increasing trend of $0.011 \mathrm{~m} \mathrm{yr}^{-1}$. For the seasons, the extreme SWH exhibits the strongest increasing trend of $0.03 \mathrm{~m} \mathrm{yr}^{-1}$ in winter and showed a decreasing trend of $-0.0098 \mathrm{~m} \mathrm{yr}^{-1}$ in autumn.

Insignificant and negative trends of extreme $\mathrm{SWH}$ in locations such as Hainan, Dongsha, Kalimantan, and Palawan are associated with shadowing, island blocking, refraction, or complex topography.

The annual 99th-percentile values of significant wave height for the study period were divided into 7 segments of 4 -year duration each and trends in 100-year return period were determined for each segment. Also, spatial trends in the values of the 100-year return period estimates are examined altogether for the segments. The results are generally insignificant with no obvious trend in 100-year return period for the 99th-percentile wave height. This is consistent with the findings of [32] in the global investigation of trends in 100year return period of 99th-percentile wave height with a time series of 4-year duration.

This paper further considered comparing linear trends in wave height over the SCS with previous works by $[4,17,28-$ 30]. Locations in the SCS having significant positive trends in extreme wave height like most locations along the California coast in the Northeast Pacific are waters in the southwest corner of the SCS and waters along the Vietnam border and close to Hainan island in northwest SCS and in few locations in northeast SCS. Regions south of latitude $12^{\circ} \mathrm{N}$ in the SCS with few waters in the northern SCS exhibit small and no significant trends similar to buoys around Alaska and Hawaiian islands. Decreasing trends dominate in most waters above $15^{\circ} \mathrm{N}$ in the SCS like that observed from some Canadian buoys in the Northeast Pacific. Strong spatial trends in extreme wave height exist in winter months of December and February. Strong temporal trends also exist in December and February. This compared with the severity of extreme wave height in the Northeast Pacific and Bering Sea between October and March (Boreal Winter).

The trend in annual mean wave height is weaker in the SCS than in the north pacific. Also, a comparison of the 99thpercentile trends in wave height in the SCS with that of the north pacific showed weaker trends in the SCS. The 99thpercentile wave height trends are increasingly more positive with higher latitudes $\pm 35^{\circ}$ of both hemispheres and also the equatorial and tropical regions of all oceanic basins show neutral trends for wave height for the mean and 99th-percentile cases. Wave height trend in the SCS becomes more positive moving from the mean to the 99 th-percentile conditions. The near-neutral trends in both mean and 99th-percentile wave height in the SCS are a result of the wave climate in tropical waters which is dominated by remotely generated swell and results in most cases show little correlation between wind speed and wave height trends in the tropics.

The trends in annual averages of the winter significant wave heights measured by US West Coast buoys at different latitudes ranged between $0.006 \mathrm{~m} \mathrm{yr}^{-1}$ for $\mathrm{Pt}$. Arguello and $0.032 \mathrm{~m} \mathrm{yr}^{-1}$ for Washington. The trend over Pt. Arguello $\left(0.006 \mathrm{~m} \mathrm{yr}^{-1}\right)$ compared better with the value $\left(0.0076 \mathrm{~m} \mathrm{yr}^{-1}\right)$ obtained during winter for the SCS. The trends in extreme value wave height during winter between the SCS and Washington differed by $0.078 \mathrm{~m} \mathrm{yr}^{-1}$. Also, the trends in the annual average wave height between the SCS and Washington differed by $0.0191 \mathrm{~m} \mathrm{yr}^{-1}$. The higher latitudinal position of Washington accounted for the large difference in trends from that of SCS.

A comparison of linear trends in the annual averages of the "winter" and "summer" significant wave heights in the 
US East Coast with that obtained in this study showed that winter exhibits a higher trend in wave height in the SCS. On the other hand, higher trends in wave height are observed during summer in the US East Coast.

The results of the long-term trends in the annual mean, winter average, and annual maximum wave height in this study are compared with a study over the US Pacific Northwest. Higher trends in all cases are observed over the US Pacific Northwest. The differences in the trends in the annual mean, winter average, and annual maximum wave height are, respectively, 0.0101, 0.0154 , and $0.084 \mathrm{~m} \mathrm{yr}^{-1}$. Furthermore, during summer, higher trends in annual average wave heights are observed in the US Pacific Northwest.

\section{Nomenclature}

SCS: South China Sea

SWH: Significant wave height

Tp: $\quad$ Peak wave period

RMSE: Root mean square error

CC: Correlation coefficient

WW3: WAVEWATCH III.

\section{Competing Interests}

The authors declare that they have no competing interests.

\section{Acknowledgments}

This work is financially supported by the National Natural Science Foundation of China (51479183 and 51509226) and the Fundamental Research Funds for the Central Universities (201513040).

\section{References}

[1] S. K. Gulev, V. Grigorieva, A. Sterl, and D. Woolf, "Assessment of the reliability of wave observations from voluntary observing ships: insights from the validation of a global wind wave climatology based on voluntary observing ship data," Journal of Geophysical Research, vol. 108, no. 7, article 3236, 2003.

[2] L. D. Wright, J. D. Boon, S. C. Kim, and J. H. List, "Modes of cross-shore sediment transport on the shoreface of the Middle Atlantic Bight," Marine Geology, vol. 96, no. 1-2, pp. 19-51, 1991.

[3] C. Bosserelle, C. B. Pattiaratchi, and I. Haigh, "Inter-annual variability and longer-term changes in the wave climate of Western Australia between 1970 and 2009," Ocean Dynamics, vol. 62, no. 1, pp. 63-76, 2012.

[4] M. Menéndez, F. J. Méndez, I. J. Losada, and N. E. Graham, "Variability of extreme wave heights in the northeast Pacific Ocean based on buoy measurements," Geophysical Research Letters, vol. 35, no. 22, 2008.

[5] J. C. Allan and P. D. Komar, "Are ocean wave heights increasing in the eastern North Pacific?" Eos, Transactions American Geophysical Union, vol. 81, no. 47, pp. 561-567, 2000.

[6] J. F. R. Gower, "Temperature, wind and wave climatologies, and trends from marine meteorological buoys in the northeast Pacific," Journal of Climate, vol. 15, no. 24, pp. 3709-3717, 2002.
[7] S. K. Gulev and V. Grigorieva, "Last century changes in ocean wind wave height from global visual wave data," Geophysical Research Letters, vol. 31, no. 24, Article ID L24302, 2004.

[8] S. K. Gulev and V. Grigorieva, "Variability of the winter wind waves and swell in the North Atlantic and North Pacific as revealed by the voluntary observing ship data," Journal of Climate, vol. 19, no. 21, pp. 5667-5685, 2006.

[9] X. L. Wang and V. R. Swail, "Changes of extreme wave heights in Northern Hemisphere oceans and related atmospheric circulation regimes," Journal of Climate, vol. 14, no. 10, pp. 2204-2221, 2001.

[10] N. E. Graham and H. F. Diaz, "Evidence for intensification of North Pacific winter cyclones since 1948," Bulletin of the American Meteorological Society, vol. 82, no. 9, pp. 1869-1893, 2001.

[11] M. A. Hemer, "Historical trends in Southern Ocean storminess: long-term variability of extreme wave heights at Cape Sorell, Tasmania," Geophysical Research Letters, vol. 37, no. 18, Article ID L18601, 2010.

[12] S. K. Gulev and L. Hasse, "North Atlantic wind waves and wind stress fields from voluntary observing ship data," Journal of Physical Oceanography, vol. 28, no. 6, pp. 1107-1130, 1998.

[13] S. K. Gulev and L. Hasse, "Changes of wind waves in the North Atlantic over the last 30 years," International Journal of Climatology, vol. 19, no. 10, pp. 1091-1117, 1999.

[14] F. J. Wentz, L. Ricciardulli, K. Hilburn, and C. Mears, "How much more rain will global warming bring?" Science, vol. 317, no. 5835, pp. 233-235, 2007.

[15] B. R. Thomas, E. C. Kent, V. R. Swail, and D. I. Berry, "Trends in ship wind speeds adjusted for observation method and height," International Journal of Climatology, vol. 28, no. 6, pp. 747-763, 2008.

[16] H. Tokinaga and S.-P. Xie, "Wave- and Anemometer-Based Sea Surface Wind (WASWind) for climate change analysis," Journal of Climate, vol. 24, no. 1, pp. 267-285, 2011.

[17] I. R. Young, S. Zieger, and A. V. Babanin, "Global trends in wind speed and wave height," Science, vol. 332, no. 6028, pp. 451-455, 2011.

[18] I. R. Young, "Global ocean wave statistics obtained from satellite observations," Applied Ocean Research, vol. 16, no. 4, pp. 235248, 1994.

[19] I. R. Young, "Seasonal variability of the global ocean wind and wave climate," International Journal of Climatology, vol. 19, no. 9, pp. 931-950, 1999.

[20] I. R. Young and G. J. Holland, Atlas of the Oceans: Wind and Wave Climate, Pergamon, New York, NY, USA, 1996.

[21] J. H. G. M. Alves and I. R. Young, "On estimating extreme wave heights using combined Geosat, Topex/Poseidon and ERS-1 altimeter data," Applied Ocean Research, vol. 25, no. 4, pp. 167186, 2003.

[22] G. Chen, S.-W. Bi, and R. Ezraty, "Global structure of extreme wind and wave climate derived from TOPEX altimeter data," International Journal of Remote Sensing, vol. 25, no. 5, pp. 10051018, 2004.

[23] V. Panchang, L. Zhao, and Z. Demirbilek, "Estimation of extreme wave heights using GEOSAT measurements," Ocean Engineering, vol. 26, no. 3, pp. 205-225, 1998.

[24] J. Vinoth, Statistical analysis of global estimates of extreme wind speed and wave height [Ph.D. thesis], Centre for Sustainable Infrastructure, Swinburne University of Technology, Hawthorne, Australia, 2011. 
[25] J. Vinoth and I. R. Young, "Global estimates of extreme wind speed and wave height," Journal of Climate, vol. 24, no. 6, pp. 1647-1665, 2011.

[26] H. Günther, W. Rosenthal, M. Schwarz et al., "The wave climate of the northeast Atlantic over the period 1955-1994: the WASA wave hindcast," The Global Atmosphere and Ocean System, vol. 6, pp. 121-163, 1998.

[27] S. Zieger, J. Vinoth, and I. R. Young, "Joint calibration of multiplatform altimeter measurements of wind speed and wave height over the past 20 years," Journal of Atmospheric and Oceanic Technology, vol. 26, no. 12, pp. 2549-2564, 2009.

[28] J. C. Allan and P. D. Komar, "Climate controls on US West Coast erosion processes," Journal of Coastal Research, vol. 22, no. 3, pp. 511-529, 2006.

[29] P. D. Komar and J. C. Allan, "Increasing wave heights along the U.S. Central Atlantic shore due to the intensification of hurricanes," Journal of Coastal Research, vol. 24, no. 2, pp. 479488, 2008.

[30] P. Ruggiero, P. D. Komar, and J. C. Allan, "Increasing wave heights and extreme value projections: the wave climate of the U.S. Pacific Northwest," Coastal Engineering, vol. 57, no. 5, pp. 539-552, 2010.

[31] A. Mirzaei, F. Tangang, L. Juneng, M. A. Mustapha, M. L. Husain, and M. F. Akhir, "Wave climate simulation for southern region of the South China Sea," Ocean Dynamics, vol. 63, no. 8, pp. 961-977, 2013.

[32] I. R. Young, J. Vinoth, S. Zieger, and A. V. Babanin, "Investigation of trends in extreme value wave height and wind speed," Journal of Geophysical Research: Oceans, vol. 117, no. 3, Article ID C00J06, 2012.

[33] H. L. Tolman, User Manual and System Documentation of WAVEWATCH-III Version 3.14, Technical Note, NOAA/NWS/ NCEP/MMAB, Washington, DC, USA, 2009.

[34] L. L. Fu, E. J. Christensen, C. A. Yamarone Jr. et al., “TOPEX/ POSEIDON mission overview," Journal of Geophysical Research, vol. 99, no. 12, Article ID 24369, 1994.

[35] P. S. Callahan, C. S. Morris, and S. V. Hsiao, "Comparison of TOPEX/POSEIDON and significant wave height distributions to Geosat," Journal of Geophysical Research, vol. 99, no. C12, pp. 25015-25024, 1994.

[36] E. Dobson, F. Monaldo, and J. Goldhirsh, "Validation of Geosat altimeter-derived wind speeds and significant wave heights using buoy data," Journal of Geophysical Research, vol. 92, pp. 10719-10731, 1987.

[37] C. W. Zheng and C. Y. Li, "Variation of the wave energy and significant wave height in the China Sea and adjacent waters," Renewable and Sustainable Energy Reviews, vol. 43, pp. 381-387, 2015. 

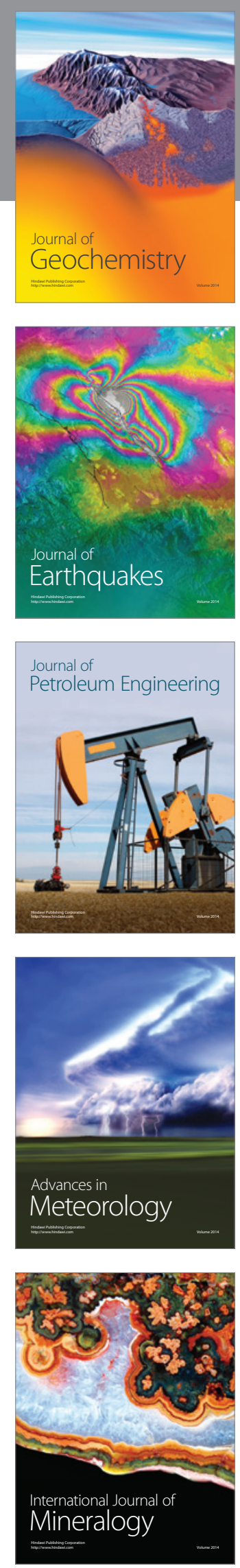
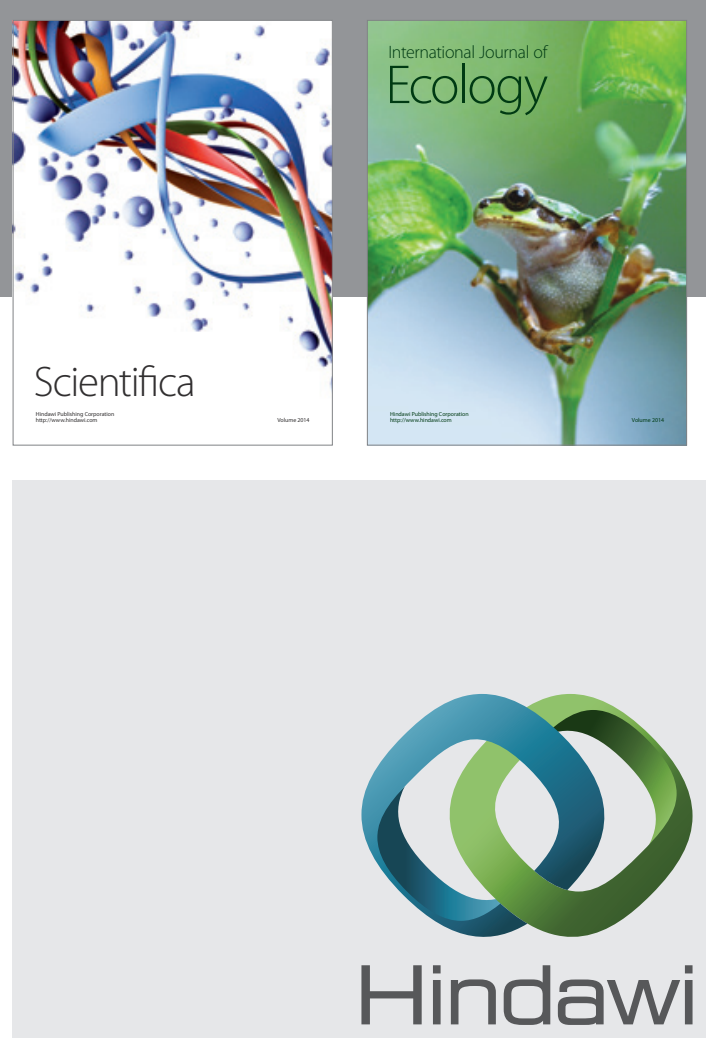

Submit your manuscripts at

http://www.hindawi.com
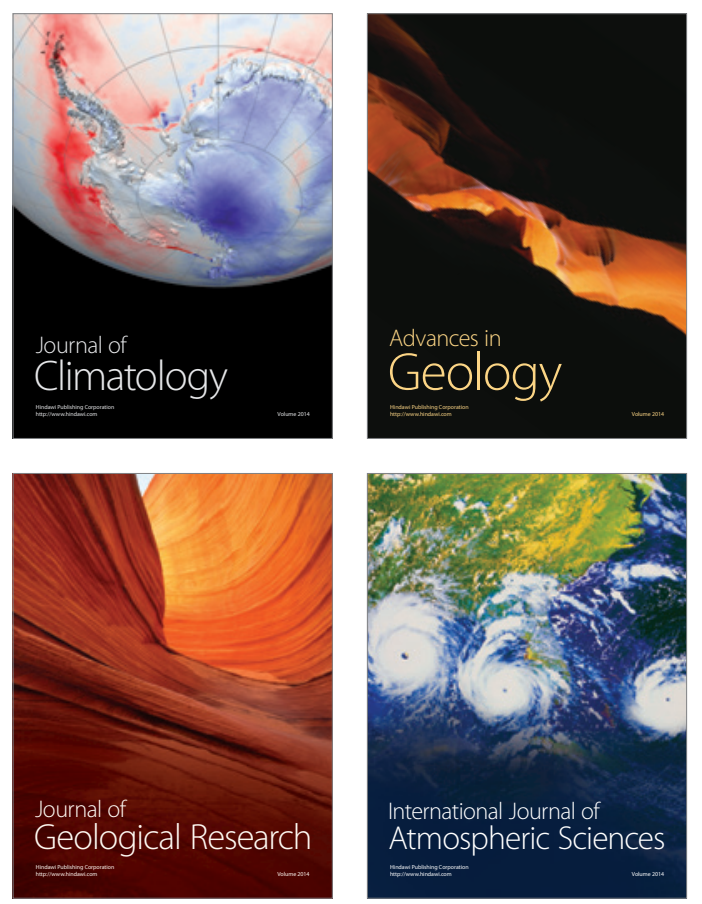

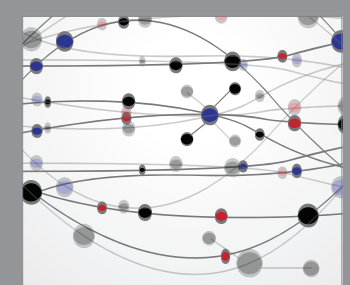

The Scientific

\section{World Journal}
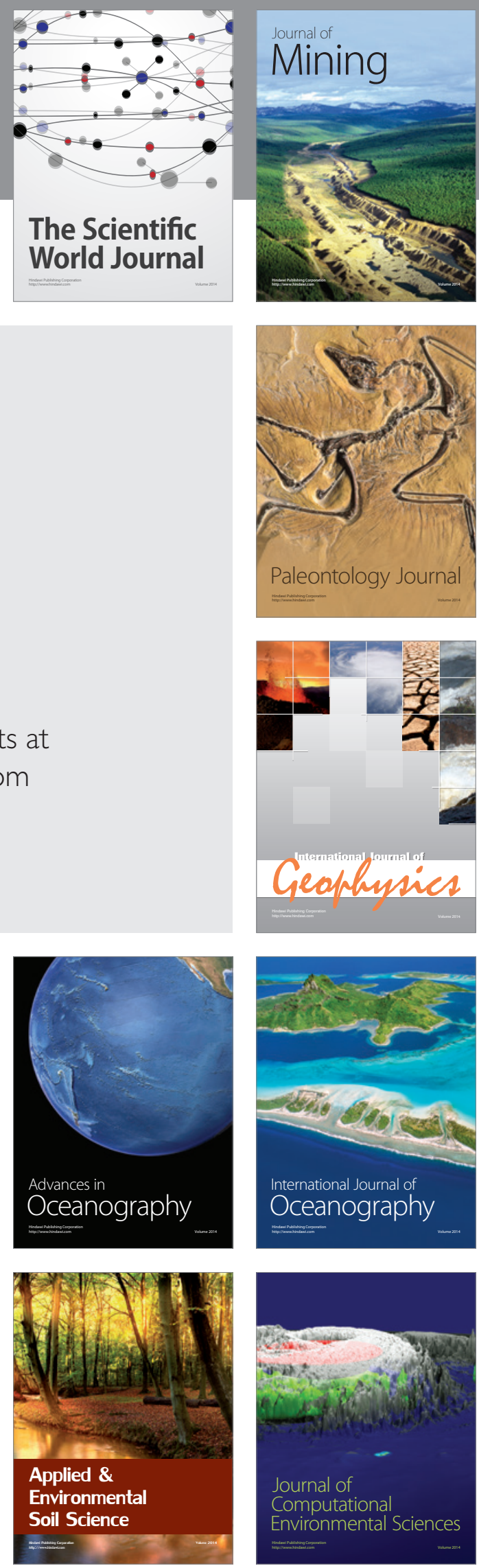